\title{
Decadal changes from a multi-temporal glacier inventory of Svalbard
}

\author{
C. Nuth ${ }^{1}$, J. Kohler ${ }^{2}$, M. König ${ }^{2}$, A. von Deschwanden ${ }^{2}$, J. O. Hagen ${ }^{1}$, A. Kääb ${ }^{1}$, G. Moholdt ${ }^{1,3}$, and R. Pettersson ${ }^{4}$ \\ ${ }^{1}$ Dept. of Geosciences, University of Oslo, Oslo Norway \\ ${ }^{2}$ Norwegian Polar Institute, Troms $\varnothing$, Norway \\ ${ }^{3}$ Institute of Geophysics and Planetary Physics, Scripps Institution of Oceanography, La Jolla, California, USA \\ ${ }^{4}$ Department of Earth Sciences, Uppsala University, Uppsala, Sweden
}

Correspondence to: C. Nuth (christopher.nuth@geo.uio.no)

Received: 17 April 2013 - Published in The Cryosphere Discuss.: 10 June 2013

Revised: 6 September 2013 - Accepted: 10 September 2013 - Published: 18 October 2013

\begin{abstract}
We present a multi-temporal digital inventory of Svalbard glaciers with the most recent from the late 2000s containing $33775 \mathrm{~km}^{2}$ of glaciers covering $57 \%$ of the total land area of the archipelago. At present, $68 \%$ of the glacierized area of Svalbard drains through tidewater glaciers that have a total terminus width of $\sim 740 \mathrm{~km}$. The glacierized area over the entire archipelago has decreased by an average of $80 \mathrm{~km}^{2} \mathrm{a}^{-1}$ over the past $\sim 30 \mathrm{yr}$, representing a reduction of $7 \%$. For a sample of $\sim 400$ glaciers $\left(10000 \mathrm{~km}^{2}\right)$ in the south and west of Spitsbergen, three digital inventories are available from the 1930/60s, 1990 and 2007 from which we calculate average changes during 2 epochs. In the more recent epoch, the terminus retreat was larger than in the earlier epoch, while area shrinkage was smaller. The contrasting pattern may be explained by the decreased lateral wastage of the glacier tongues. Retreat rates for individual glaciers show a mix of accelerating and decelerating trends, reflecting the large spatial variability of glacier types and climatic/dynamic response times in Svalbard. Lastly, retreat rates estimated by dividing glacier area changes by the tongue width are larger than centerline retreat due to a more encompassing frontal change estimate with inclusion of lateral area loss.
\end{abstract}

\section{Introduction}

Glacier inventories are important for studying the global frozen freshwater resource, and provide a basic dataset for further glaciological, remote sensing and modeling studies. The World Glacier Inventory (WGI), the first global glacier catalogue, was compiled with classification schemes based on hydrological drainage basins (Müller et al., 1977). WGI contains auxiliary information such as topographic parameters, length and volume estimates, and glacier characterization codes, but it does not include the digitized coordinates of the glacier outlines (WGMS, 1989). Recently, the Global Land Ice Measurements from Space (GLIMS) initiative has provided a scheme for generating a global glacier inventory that retains the raw glacier outline information (Raup et al., 2007). There are some inherent differences between GLIMS and WGI in their structure, application and information they provide (Cogley, 2009), but regional glacier inventories can be relatively easily submitted and linked to both datasets (e.g. Paul et al., 2009; Bolch et al., 2010; Svoboda and Paul, 2010). Moreover, the increasing ease of generating glacier inventories semi-automatically from satellite imagery (Paul et al., 2013) combined with the more frequent coverage of planned satellite missions (e.g. Sentinel-2) facilitate such investigations of multi-temporal glacier inventory changes.

The Arctic archipelago of Svalbard in the North Atlantic is $\sim 57 \%$ glacierized and contains a mix of cirque and valley glaciers, ice fields and ice caps. There are both landterminating and tidewater glaciers; most of them are polythermal and many exhibit surge-type behavior. The surface mass balance has generally been negative since the termination of the Little Ice Age, which ended around Svalbard in the beginning of the 1920s; by this time most glaciers had reached their maximum Neocene extent (Hagen et al., 1993, 2003). Summer temperatures increased dramatically during the 1920s and 1930s (Nordli and Kohler, 2004) in this part 
of the Arctic, a period sometimes referred to as the Early 20th Century Warming (Wood and Overland, 2010). Following a colder period from the 1940s to the 1960s, summer temperatures on Svalbard have been increasing. For the period 1989-2011, summer temperatures have been increasing at rates of more than $0.5^{\circ} \mathrm{C}_{\text {decade }}-1$ at the two long-term meteorological stations (Førland et al., 2011). This has led to increased glacier volume loss, particularly in western Svalbard (e.g. Kohler et al., 2007; James et al., 2012).

In this study, we present glacier extent snapshots and change rates from the 1930s to 2010 based on 3 digital glacier inventories: $\mathrm{GI}_{\text {old }}, \mathrm{GI}_{90}$ and $\mathrm{GI}_{00 \mathrm{~s}}$. The inventories are a key component of a new digital glacier database (König et al., 2013) that is structured after the Glacier Atlas of Svalbard and Jan Mayen (Hagen et al., 1993), the first complete glacier inventory of the archipelago (referred to as H93 in the rest of this text). $\mathrm{GI}_{\text {old }}$ and $\mathrm{GI}_{90}$ are derived from two Norwegian Polar Institute map products; the first is a mixed product of the years 1936, 1960, 1961, 1966, 1969, 1970, and 1971 , and the second is from 1990 . $\mathrm{GI}_{00 \text { s }}$ updates the previous inventories using satellite imagery from the years 2000 2010. We describe the present glaciation of the archipelago through topographic and glaciologic inventory parameters. Furthermore, we discuss the generation and applicability of three glacier inventory change parameters as derived for two epochs: (1) area changes, (2) length changes as estimated by two methods, and (3) glacier tongue width change.

\section{Data}

\subsection{Historic data}

Accurate topographic mapping of Svalbard began in the 1950s, when the Norwegian Polar Institute (NPI) undertook to construct maps using analogue photogrammetry of oblique aerial photographs taken in 1936 and 1938. These early maps covered southern and western Spitsbergen, about $22 \%$ of the archipelago. From the late 1950s to the early 1970s, a number of aerial campaigns acquired vertical photographs covering $\sim 50 \%$ of the archipelago, with major campaigns in 1966 for northern Spitsbergen and in 1971 for Edgeøya/Barentsøya. Taken together, these maps formed the original S100 (1: 100 000) topographic map series published and distributed by NPI as paper maps. The original S100 map series was digitized by NPI in the 1990s, and forms the basis for $\mathrm{GI}_{\text {old }}$.

H93, the original glacier inventory of Svalbard (Hagen et al., 1993), followed the identification and parameter definitions outlined by WGMS (1989). It was based upon the S100 paper maps (before digital transformation) but with the oldest data (1936 and 1938) updated using pre-1980 aerial and Landsat imagery. Front positions and areas of H93 were measured from these updated paper maps using a planimeter. The inventory consists of basic data such as glacier name, area, length, and photo year in table format, but the raw outline locations are not preserved and thus not available digitally in a GIS (geographic information system). For consistency, we preserve the same structure for our new digital glacier inventory.

A second major mapping campaign was conducted by NPI in 1990 to acquire vertical aerial photographs over nearly the entire archipelago. In the 1990s and 2000s, NPI created topographic and thematic maps for about $60-70 \%$ of the archipelago using digital photogrammetric techniques and manual feature delineation, which forms the basis for $\mathrm{GI}_{90}$. There are two exceptions in this updated dataset: the south coast of Austfonna front position was mapped by helicopter with GPS in 1992 (T. Eiken, personal communication, 2013), and a small inland strip within southern Spitsbergen was covered with 1961 and 1970 images (H. Faste Aas, personal communication, 2013). The spatial and temporal coverage of all glacier inventories can be seen in Fig. 1 .

\subsection{Satellite imagery}

Summer satellite imagery spanning the period 2000-2010 is used as the basis for our third glacier dataset, $\mathrm{GI}_{00 \mathrm{~s}}$ (Table 1). We prioritize data from sensors that obtain stereo optical imagery for creation of orthophotos that are temporally and spatially consistent with the digital elevation models (DEMs) used to generate them. Accordingly, the main data are the DEMs and orthophotos from the SPOT5-HRS (highresolution sensor) satellite, generated by the IPY project SPIRIT (SPOT 5 stereoscopic survey of Polar Ice: Reference Images and Topographies) (Korona et al., 2009). The SPOT5-HRS collects $5 \mathrm{~m}$ panchromatic stereo images that are stereoscopically processed into $40 \mathrm{~m}$ DEMs, which are then used for generating orthophotos of the original images. Five SPIRIT acquisitions from 2007 to 2008 cover $71 \%$ of the glacierized area of Svalbard.

The second main satellite data source is the ASTER L1B product, in the form of automatically generated DEMs and orthophotos (AST14DMO, 2010). These have a smaller swath width $(60 \mathrm{~km})$ than SPOT5, such that 23 scenes are needed to cover $\sim 16 \%$ of the glacier area. Cloud-free scenes were not available for 2007-2008, and therefore data from as early as 2000 were required to complete coverage of the archipelago. For the remaining $14 \%$ of the glacier area, no suitable SPOT5-HRS or ASTER scenes were available. For these glaciers, 11 orthorectified Landsat scenes from 2001 to 2007 are used. An additional 17 Landsat and 13 ASTER scenes are used to aid decisions related to perennial snow patches and to delineate glacier margins in areas with seasonal snow cover or shade.

\subsection{Satellite DEMs}

We use the ASTER GDEM (v2) for separating glaciers into individual hydrological units and for prescribing topographic 


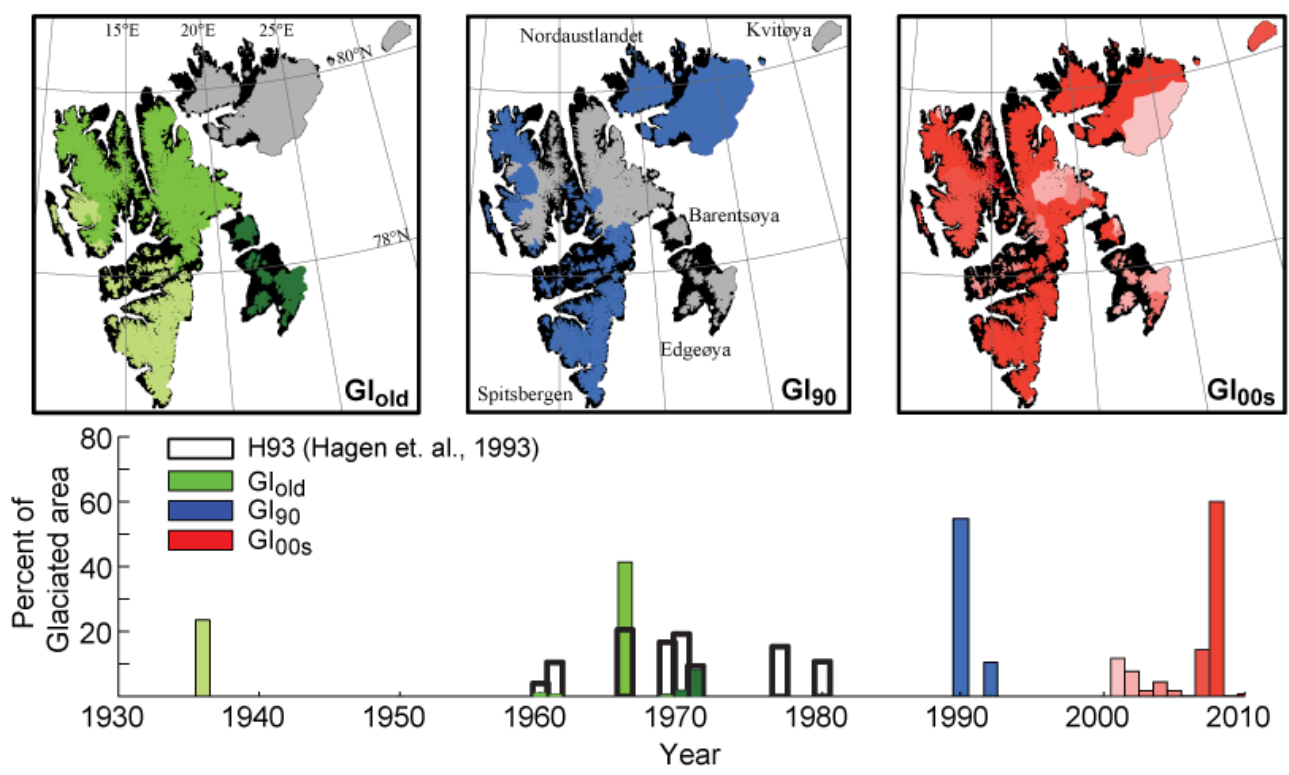

Fig. 1. Spatial and temporal coverage of glacier inventories (GI). The three maps (top) and the filled bars (bottom) show digitally available outlines. The black unfilled bars are the $\mathrm{H} 93$ tabular inventory (Hagen et al., 1993). The satellite-based inventory, $\mathrm{GI}_{00 \mathrm{~s}}$ (in red), is the first digital inventory covering the entire archipelago. The shades of individual colors in the maps represent time within each inventory. Lighter shades are earlier; i.e. the lightest green is from 1936 and the lightest red from 2001. Grey represents no data.

attributes to the glaciers (Frey and Paul, 2012). The GDEM is a global compilation of stacked and filtered ASTER DEMs (Fujisada et al., 2012) that temporally overlaps $\mathrm{GI}_{00 \mathrm{~s}}$. GDEM is chosen over other DEMs (SPOT/ASTER) for its consistency as a single product covering the entire archipelago. Glacier surfaces in the GDEM have a bumpy texture, a result of the merging of temporally different DEMs of varying quality, especially on the low visual contrast upper glacier areas. Therefore, a low-pass Fourier filter is applied over glacier surfaces to remove the high-frequency noise and minimize the size of the blunders that occur at the highest elevations (see Appendix A). The filtering reduced standard deviations of elevation differences with respect to ICESat and SPOT-SPIRIT DEMs and improved visual appearance of the GDEM without changing the overall structure of the surface. Moreover, visual comparisons between the GDEM-derived hydrological basins and those derived from the NPI topographic maps/DEMs, the SPOT-SPIRIT DEMs and individual AST14DMO (2010) DEMs reveal small variations which verify the use of the GDEM for this purpose and infer that rough DEM quality does not have a large impact on drainage basin generation. The largest discrepancies (blunders) occur on the flattest upper regions of ice cap and ice fields where small elevation inconsistencies can sometimes lead to large differences in the determination of a hydrological divide. These blunders are manually adjusted to the drainage basins derived from the other DEMs. For the Austfonna ice cap, where the GDEM contains several holes, we use an independently created DEM (Moholdt and Kääb, 2012), as well as velocity fields derived from SAR interferograms (Strozzi et al., 2008; Dowdeswell et al., 2008) to delineate ice divides and glacier basins and to generate topographic parameters.

\section{Methods}

\subsection{Georeferencing}

The various DEMs and orthoimages must be correctly georeferenced for merging into a common dataset. While the SPOT5 and ASTER orthoimages are internally consistent with the associated DEMs, the geolocation accuracy is dependent upon the accuracy of the satellite position determination (orbital parameters) and instrument pointing (auxillery attitude information), and thus the relative DEM/orthophoto may not necessarily be located precisely on the ground. We co-register the DEMs to ICESat laser altimetry data (Zwally et al., 2012) over non-glacier topography (Nuth and Kääb, 2011) and apply the horizontal component of the correction vector to the orthoimages. We reference ICESat rather than the NPI S100 map series because ICESat data are acquired in a consistent way over the entire archipelago, while S100 is a merged product originating from various sources (analogue and digital photogrammetry) and dates (1960s-1990s). The horizontal consistency of ICESat to the 1990 DEM is $\approx \pm 3 \mathrm{~m}$ (Nuth and Kääb, 2011). For the LANDSAT scenes, manual co-registration is performed by applying a linear translation based on tie points from NPI coastline vector data and the available co-registered satellite imagery. 
Table 1. Data sources used for the compilation of the most recent Svalbard glacier inventory, $\mathrm{GI}_{00 \mathrm{~s}}$.

\begin{tabular}{|c|c|c|c|c|}
\hline Source & Satellite ID & Date & \# of glaciers & Glacier area $\left(\mathrm{km}^{2}\right)$ \\
\hline SPOT5-HRS & GES07-043 & 1 Sep 2007 & 214 & 3951 \\
\hline SPOT5-HRS & SPI08-024 & 7 Jun 2008 & 160 & 4185 \\
\hline SPOT5-HRS & SPI08-025 & 1 Sep 2008 & 414 & 7708 \\
\hline SPOT5-HRS & SPI08-026 & 23 Jul 2008 & 106 & 1147 \\
\hline SPOT5-HRS & SPI08-027 & 14 Aug 2008 & 73 & 6912 \\
\hline ASTER & AST-L1A.003:2003897557 & 19 Aug 2001 & 2 & 72 \\
\hline ASTER & AST-L1A.003:2007646255 & $1 \mathrm{Jul} 2002$ & 5 & 707 \\
\hline ASTER & AST-L1A.003:2007714532 & $12 \mathrm{Jul} 2002$ & 10 & 34 \\
\hline ASTER & AST-L1A.003:2007742577 & $13 \mathrm{Jul} 2002$ & 16 & 1331 \\
\hline ASTER & AST-L1A.003:2007910399 & 25 Jul 2002 & 35 & 71 \\
\hline ASTER & AST-L1A.003:2007986699 & 13 Aug 2002 & 30 & 297 \\
\hline ASTER & AST-L1A.003:2009046998 & 17 Aug 2000 & 1 & 1 \\
\hline ASTER & AST-L1A.003:2015307203 & 12 Jul 2003 & 59 & 133 \\
\hline ASTER & AST-L1A.003:2015307217 & $12 \mathrm{Jul} 2003$ & 7 & 29 \\
\hline ASTER & AST-L1A.003:2015307219 & 12 Jul 2003 & 50 & 106 \\
\hline ASTER & AST-L1A.003:2015475397 & $22 \mathrm{Jul} 2003$ & 32 & 289 \\
\hline ASTER & AST-L1A.003:2025002689 & $11 \mathrm{Jul} 2004$ & 32 & 79 \\
\hline ASTER & AST-L1A.003:2025063344 & 13 Jul 2004 & 24 & 63 \\
\hline ASTER & AST-L1A.003:2025063353 & 13 Jul 2004 & 2 & 331 \\
\hline ASTER & AST-L1A.003:2025063355 & 13 Jul 2004 & 10 & 775 \\
\hline ASTER & AST-L1A.003:2025232928 & 7 Aug 2004 & 26 & 181 \\
\hline ASTER & AST-L1A.003:2029911903 & 7 Jun 2005 & 79 & 151 \\
\hline ASTER & AST-L1A.003:2030201287 & 24 Jul 2005 & 10 & 360 \\
\hline ASTER & AST-L1A.003:2030201290 & $24 \mathrm{Jul} 2005$ & 11 & 39 \\
\hline ASTER & AST-L1A.003:2035266221 & $20 \mathrm{Jul} 2006$ & 25 & 51 \\
\hline ASTER & AST-L1A.003:2075205746 & 1 Aug 2009 & 2 & 6 \\
\hline ASTER & AST-L1A.003:2075205748 & 12 Aug 2009 & 9 & 12 \\
\hline ASTER & AST-L1A.003:2080297809 & 15 Jul 2010 & 57 & 247 \\
\hline Landsat & L71208005-00520020712 & 12 Jul 2002 & 6 & 31 \\
\hline Landsat & L71211002-00220070715 & 15 Jul 2007 & 1 & 647 \\
\hline Landsat & L71212004-00420020622 & 22 Jun 2002 & 1 & 1 \\
\hline Landsat & L71213004-00420050723 & 23 Jul 2005 & 6 & 6 \\
\hline Landsat & L71215002-00220010710 & $10 \mathrm{Jul} 2001$ & 7 & 3783 \\
\hline Landsat & L71215003-00320020713 & 13 Jul 2002 & 9 & 12 \\
\hline Landsat & L71219003-00320020709 & 9 Jul 2002 & 14 & 55 \\
\hline Landsat & L71220002-00220070714 & 14 Jul 2007 & 7 & 9 \\
\hline Landsat & L72215003-00320020713 & 13 Jul 2002 & 3 & 3 \\
\hline Landsat & L72217003-00320020711 & $11 \mathrm{Jul} 2002$ & 3 & 5 \\
\hline Landsat & L72219003-00320020709 & 9 Jul 2002 & 2 & 1 \\
\hline
\end{tabular}

\subsection{Glacier delineation and identification}

The raw outlines that form the historic inventories of $\mathrm{GI}_{\text {old }}$ and $\mathrm{GI}_{90}$ were generated by cartographers who visually interpreted and digitized the glacier borders from the original images using analogue photogrammetric workstations for the oldest dataset $\left(\mathrm{GI}_{\text {old }}\right)$ and digital orthoimages for $\mathrm{GI}_{90}$. These outlines were highly detailed (high resolution) with accurate glacier front positions; however, many of the raw outlines contained seasonal snow-covered valley walls and gullies higher up on the glaciers from misinterpretation by the cartographers. These were trimmed by visual analysis of the multi-temporal satellite archives where it was obvious that the cartographers digitized snow-filled gullies, which are not considered a part of the glacier and were removed by best judgment rather than using a minimum size criteria.

These historic glacier outlines did not distinguish between individual glaciers, but rather were complex polygons. We combine the raw digitized glacier outlines from S100 maps (1936-1971) with the analogue H93 inventory to create $\mathrm{GI}_{\text {old }}$. Glacier basins are delineated based on the H93 local identification codes (WGI IDs) and glacier names, and with the visual help of all available automatically generated hydrological basins, topographic contours and optical satellite imagery (Sect. 2). GI old is then used as a reference to separate 


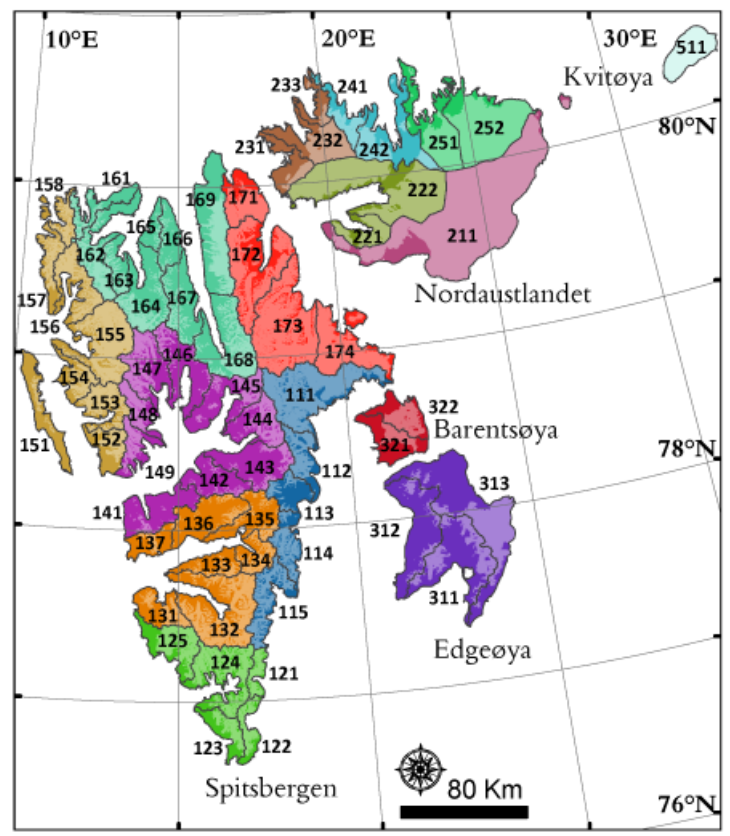

\section{Regional Glacier Hypsometry}
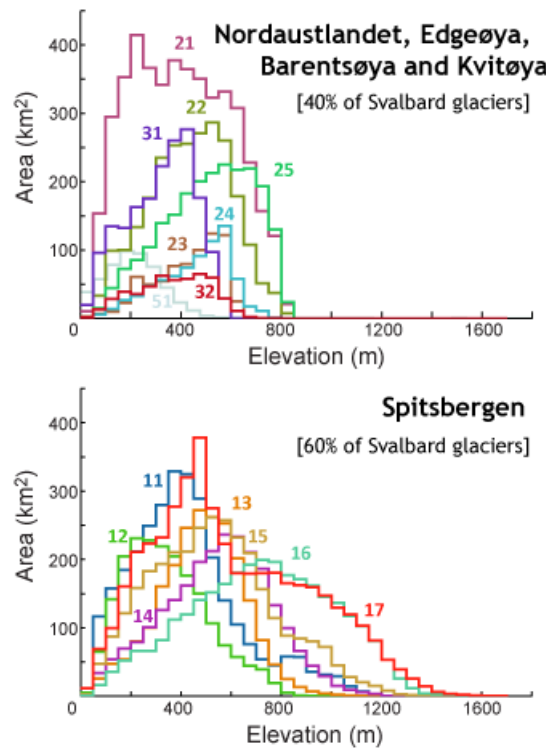

Fig. 2. Regions, primary and secondary drainage basins (i.e. the first three digits of the IDs). The colors depict the primary drainage basins (i.e. the first two digits of the IDs) and correspond to the colors in the glacier hypsometries shown to the right. Glacier hypsometries are extracted from the ASTER GDEM.

glacier basins (Racoviteanu et al., 2009) in the 1990 outlines, forming the $\mathrm{GI}_{90}$ inventory. Finally, the $\mathrm{GI}_{00 \mathrm{~s}}$ dataset is created from the most recent of either $\mathrm{GI}_{90}$ or $\mathrm{GI}_{\text {old }}$ by manually trimming or reshaping the front position and the lateral edges of the glacier tongue to the more recent satellite orthophotos. The basis of the outline reshaping is visual interpretation of the satellite optical images using contrast stretching to aid the delineation of the glacier margin. Outlines were also updated in the upper regions of the glaciers when nunataks appeared or large changes were present due to upper glacier downwasting, for example from a surge.

The local identification system for individual glaciers is defined hydrologically by the WGI IDs of H93 comprising 5 digits:

- 1st digit represents the division of the archipelago into 5 major regions: (1) Spitsbergen, (2) Nordaustlandet, (3) Barentsøya, (4) Egdeøya, and (5) Kvitøya.

- 2nd digit is the division of each region into primary drainage basins.

- 3rd digit is the division into secondary drainage basins.

- 4th and 5th digits are the number for each individual glacier.

For example, if a glacier is denoted by 14204 , then the glacier lies in region 1 (Spitsbergen), in major drainage basin 4 (Isfjorden), and in secondary drainage basin 2 (Adventdalen), and its glacier number is 04 (Longyearbreen). An overview map of the regions and drainage basins is shown in Fig. 2.

The original H93 glacier identification system required adaptation since a number of individual WGI glacier units in H93 comprised single tongues fed by multiple tributary ice streams that can now be divided into new discrete flow units. Either the old glacier front has retreated and naturally separated into separate tongues or the tributary glaciers have significant medial moraines suggesting a natural division of the glacier system. These new independent glacier units retain the original H93 ID, but with additional decimals to identify the individual glacier entities (see Fig. 3). In addition, a few of the flow divides on the 2 larger ice caps have been adjusted based upon updated information (Sect. 2.3) that was not available in the creation of $\mathrm{H} 93$.

Lastly, an inventory requires also definitions of the smallest snow patches and glacierets (Cogley et al., 2011). $\mathrm{GI}_{00 \mathrm{~s}}$ defines glacierets and snow patches as those visually and perennially present in the temporal series of Landsat and ASTER images, the smallest of which is $0.05 \mathrm{~km}^{2}$. H93 defines glacierets and snowpatches as perennial snow/ice areas less than $1 \mathrm{~km}^{2}$, and these units were not given specific IDs. Therefore, these units are labeled in $\mathrm{GI}_{00 \text { s }}$ based on their secondary drainage basin, using 99 as the glacier number (4th and 5th digits) with increasing decimals for each individual unit (14299.01 in the above example). 

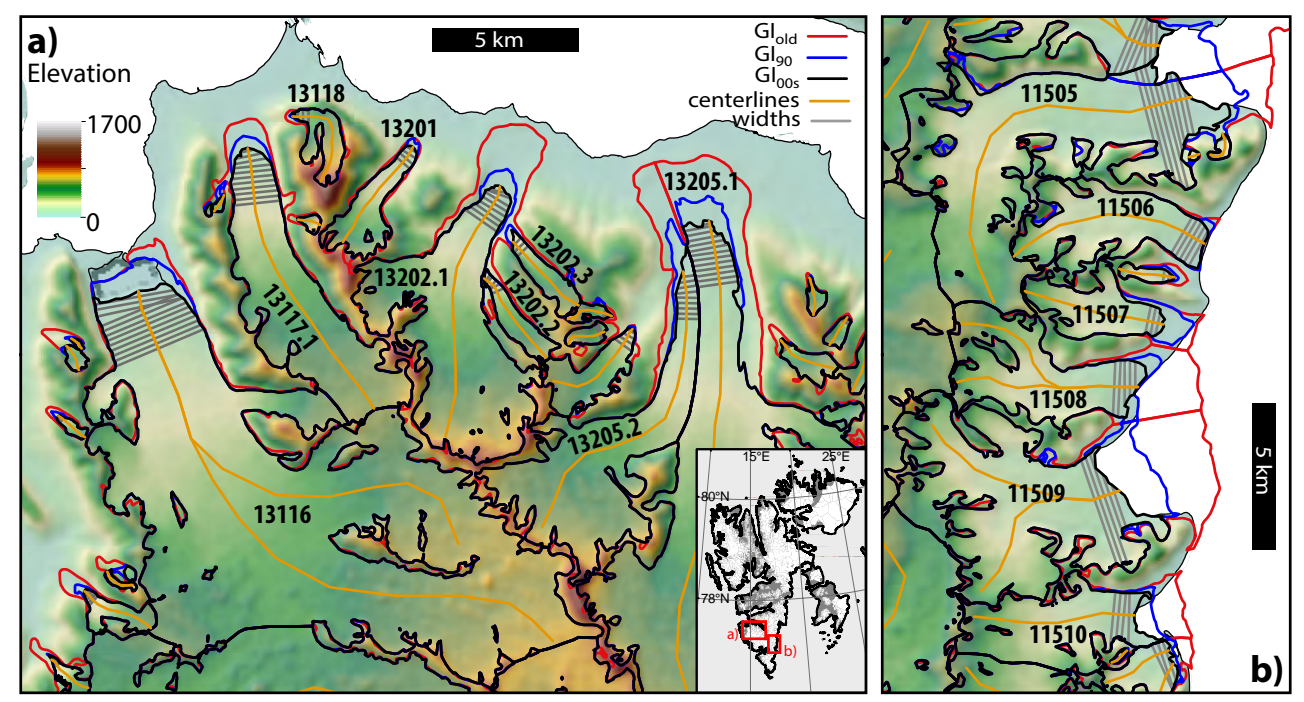

Fig. 3. Examples of the digital inventories from a selection of (a) land-terminating and (b) tidewater glaciers in southern Spitsbergen. Selected glaciers are shown with their local identification codes, centerlines and glacier tongue widths. Note that only centerlines and tongue widths from the lowest $10 \%$ of the centerline of the $\mathrm{GI}_{00 \mathrm{~s}}$ are shown.

\subsection{Glaciological and topographic attributes}

For the $\mathrm{GI}_{00 \text { s }}$ inventory, a number of descriptive, glacier and topographic attributes are extracted for each individual glacier entity, as suggested by Paul et al. (2009). The standard geometric and topographic parameters include polygon area, polygon perimeter, elevation minimum, maximum, median and standard deviation, mean slope and mean aspect. Glacier hypsometries are extracted for $50 \mathrm{~m}$ elevation bins from the ASTER GDEM; these are shown in Fig. 2 for the primary drainage basins.

Two additional glaciological parameters are generated for the three inventories: glacier length and the average width of the glacier tongue. At least one centerline is manually digitized for each glacier area polygon, from the glacier tongue to the head of the accumulation area. If a single glacier entity contains more than one centerline, the maximum length is provided. The centerlines are then used to generate glacier tongue width. Lines perpendicular to the centerline are intersected with the glacier outlines for each GI. The glacier tongue or terminus width is then estimated as the average measured width of the lowermost $10 \%$ of the centerline for $\mathrm{GI}_{00 \mathrm{~s}}$. The threshold is chosen visually to best represent the varying tongue shapes of both small and large glaciers collectively. Varying the threshold by $5 \%$ has little effect except for the smallest glaciers with pointy glacier tongue shapes. For $\mathrm{GI}_{90}$ and $\mathrm{GI}_{\mathrm{old}}$, if the centerline length change is greater than $10 \%$ of the earlier centerline, the average width along the area of change is used to ensure estimates are representative for the area of change within an epoch. For glaciers containing multiple centerlines, the average front width of all centerlines are provided. For glaciers that have 2 separate tongues corresponding to individual centerlines, the sum of front widths is given. Glacier tongue widths serve two purposes in the inventory. The first is to estimate a calving front width and the second is for change analysis. Examples of the basic geometric structures of the inventories are shown in Fig. 3 and a list of attributes is given in Table 3.

\subsection{Glacier change parameters}

A common parameter for comparing multi-temporal inventories is area change (e.g. Le Bris et al., 2011; Davies and Glasser, 2012), expressed either as mean annual area change or relative change rates as a percentage. Analysis of raw and relative area changes alone is complicated by its dependence on glacier area, tongue width and other geometrical parameters. Therefore, we also derive length changes by two methods. First, centerline length change rates are calculated as the difference in centerline length between the inventories, divided by the time interval. Second, we use an adaptation of the "box method" employed in Greenland (Moon and Joughin, 2008; Box and Decker, 2011; Howat and Eddy, 2011), which provides an average change across the glacier tongue rather than a single estimate dependent upon the location of the centerline. In our approach, an average length change rate is defined as the area change below the $\mathrm{GI}_{00}$ s median elevation divided by the oldest glacier tongue width (as described above) and subsequently by the time interval. We refer to this length change estimate as the "area/width" length change.

Each GI contains glacier outlines from multiple times (Fig. 1). This complicates the interpretation of changes between the entire inventories. However, each individual glacier outline contains a single date associated with an image.Therefore, all change rates provided are specifically 


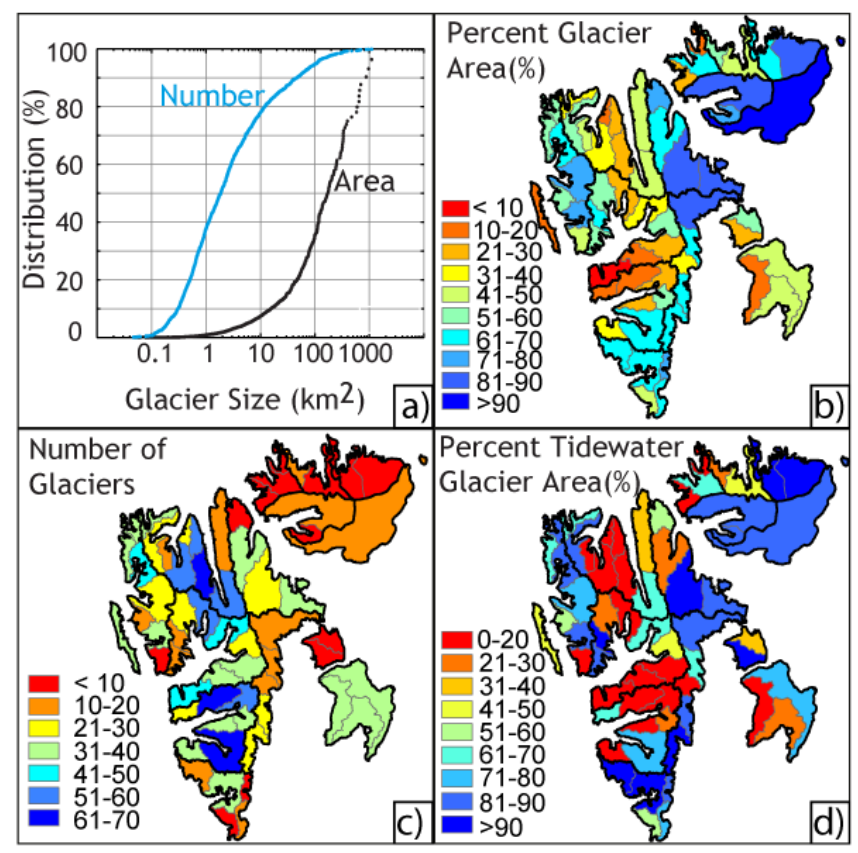

Fig. 4. (a) Glacier number and area distribution of the $\mathrm{GI}_{00 \mathrm{~s}}$ inventory. E.g. $80 \%$ of the glaciers in the inventory are less than $10 \mathrm{~km}^{2}$, which makes up less than $10 \%$ of the total Svalbard glacierized area. (b) Percent glacierized area of the secondary drainage basins. (c) Number of glaciers within secondary drainage basins reflects an inverse relationship to the percent glacierized area. (d) Percent tidewater glacier area for each secondary drainage basin shows the dominance of tidewater glaciers in Nordaustlandet and the three ice field clusters in Spitsbergen (south, northwest and northeast).

calculated for each glacier's individual time separation between outlines. Moreover, entire inventory comparisons are made by first calculating the change rates for individual outlines and then summing to drainage basin or region.

\section{Results}

\subsection{Inventory characteristics}

The newest inventory, $\mathrm{GI}_{00 \mathrm{~s}}$, contains 1668 individually labeled glacier units (including snowpatch and glacier IDs with a decimal) totaling $33775 \mathrm{~km}^{2}$, or about $57 \%$ of the total land area of the archipelago. The distributions of glacier lengths and sizes are approximately log-normal; there are about 350 glaciers ( $22 \%$ of the inventory) larger than $10 \mathrm{~km}^{2}$ that make up $93 \%$ of the glacier area (Fig. 4a). Similarly, there are 630 glaciers, glacierets and snowpatches smaller than $1 \mathrm{~km}^{2}$ that represent $38 \%$ of the inventory and $1 \%$ of the glacier area (Table 2). Glacier centerline lengths range from $200 \mathrm{~m}$ to $60 \mathrm{~km}$, with an average of $4.5 \mathrm{~km}$. A significant loglinear (power-law) relationship exists between glacier area and length, as predicted by theory (Bahr, 1997) and shown with global inventory data (Bahr and Radić, 2012).
About $68 \%$ of the glacierized area drains through tidewater calving fronts; their spatial distribution is shown in Fig. 6. The exact number of tidewater glaciers depends on how a glacier is defined. H93 labeled 152 glaciers with a calving front. In $\mathrm{GI}_{00 \mathrm{~s}}$, 197 glaciers with unique identification codes (including decimals) are characterized as tidewater terminating. Twenty-nine of these individually labeled glacier units share the calving glacier tongue with other glaciers but are clearly divided by medial moraines; this leaves 168 calving fronts. Blaszczyk et al. (2009) classified 163 tidewater glaciers, with the difference of 5 glaciers comprising 11 glaciers not classified as tidewater in $\mathrm{GI}_{00 \text { s }}$ and 6 glaciers not classified as tidewater in Blaszczyk et al. (2009).

Summing the estimated front widths for tidewater glaciers results in a calving front length of $740 \mathrm{~km}$, about half $(386 \mathrm{~km})$ of which are tidewater fronts in Spitsbergen. Our glacier tongue widths represent flux gates rather than the precise calving front length. Since lateral edges of many tidewater glaciers in Spitsbergen are grounded on land, our width estimates may often be larger than the active dynamical flux gate of the glacier. The difference with another calving front length estimate of $860 \mathrm{~km}$ (Blaszczyk et al., 2009) is due to our smaller front widths on the lobate tongues of ice cap outlet glaciers in Nordaustlandet $(215 \mathrm{~km})$, Edgeøya $(23 \mathrm{~km})$ and Kvitøya $(113 \mathrm{~km})$.

The islands to the east and northeast of Spitsbergen (Edgeøya, Barentsøya and Nordaustlandet) contain the flattest topographies, and thus glaciers there have lower slopes (Fig. 5b) and are mostly characterized by ice cap geometries. Consequently, glacier hypsometries typically feature an abrupt truncation at the highest elevations (Fig. 2). These islands contain about $40 \%$ of the glacierized area of Svalbard, with heavy glaciation on Nordaustlandet (60-90\%) and to a lesser extent on Barentsøya/Edgeøya (Fig. 4b). Maximum and median elevations are lower for the ice caps of Barentsøya and Edgeøya (Figs. 2 and 5a). About $80 \%$ of the Nordaustlandet glacier area drains through tidewater calving fronts, while only $47 \%$ of the Barentsøya/Edgeøya glacier area is tidewater (Fig. 4d).

Spitsbergen contains more alpine topography than the islands to the east. Ahlmann et al. (1933) described the "Spitsbergen style" glacier as "continuous ice masses divided into individual ice streams by mountain ridges and nunatak areas". Spitsbergen glacier hypsometries are more normally distributed than those of the ice caps to the northeast (Fig. 2). The area-elevation distributions are positively skewed, indicating a greater hypsometric weight towards lower elevations. Three clusters of interconnected ice fields exist in northwest, northeast and south Spitsbergen. These ice field clusters are divided by a less glacierized central and northcentral interior (Fig. 4b). This central region contains the largest numbers of glaciers (Fig. 4c) with the highest median elevations and steeper average slopes (Fig. 5a, b), reflecting the more cirque-style glaciation in these alpine areas. The three ice field clusters contain all the tidewater glaciers of 


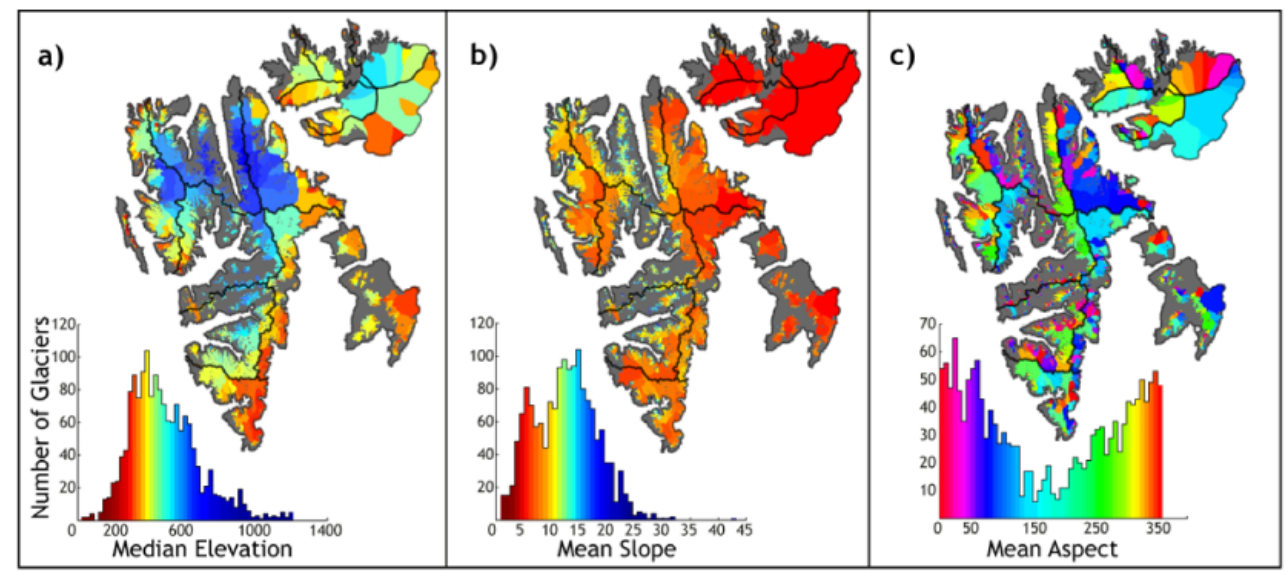

Fig. 5. Spatial distribution of (a) median elevation, (b) mean slope in degrees and (c) mean aspect in degrees from north. The color scale is shown as a histogram with the number of glaciers. The distribution of mean slope is slightly bimodal, reflecting two styles of glaciation: the flatter glaciers and icecaps that fill valley floors, and the steeper cirque-style glaciers that sit higher up along the valley walls. The distribution of mean aspect per glacier suggests a dominance of north-facing glaciers; however, histograms of all glacier DEM pixel aspects show a uniform distribution with aspect. The histogram thus reflects the dominance of small glaciers facing northward.

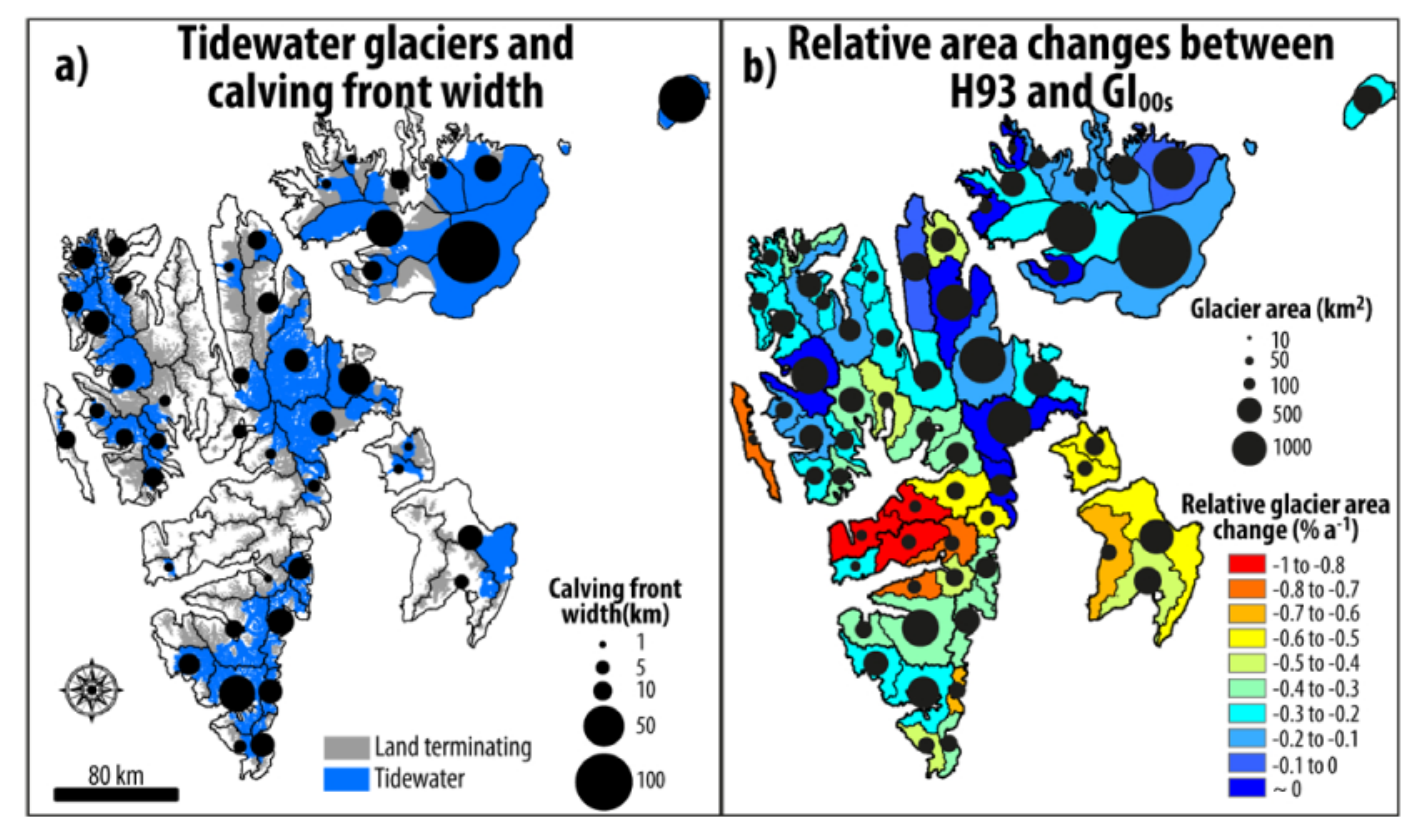

Fig. 6. (a) Distribution of land-terminating and tidewater glaciers in Svalbard. The sum of tidewater glacier front widths within each secondary drainage basin is shown as size (area)-proportional circles. (b) Relative glacier area changes between $\mathrm{H}_{93}$ and $\mathrm{GI}_{00 \mathrm{~s}}$ for each secondary drainage basin, with total glacier area shown as size (area) proportional symbols. 
Table 2. Glacier statistics for the major drainage basins of Svalbard for $\mathrm{H} 93$ and $\mathrm{GI}_{00 \mathrm{~s}}$ (in bold). Total area is the size of the drainage basin, both glacier and land. "Glacierized area" is the total glacierized area in each atlas. Differences in this parameter include glacier change and ommission/commission errors between the datasets. "Comparable glacier area" is the area corresponding to similar IDs in both inventories excluding snow patches and glacierets (see Sect. 3.2). Differences in this parameter include glacier changes and an error associated with delineating glaciers. "Percent area change" is derived from "omparable glacier area". The number of glacier units is provided only for GI 00 s as the number of unique 5-digit IDs (no decimals) provides the total number for H93. For $\mathrm{GI}_{00 \mathrm{~s}}$, this is the number of merged integer IDs. Also shown is the number of individual snow patches $\left(\mathrm{GI}_{00 \mathrm{~s}} \mathrm{IDs}=\mathrm{XXX} 99 . \mathrm{XX}\right)$ and glaciers less than $1 \mathrm{~km}^{2}(\mathrm{H} 93)$ along with the area sums. All area estimates have unit $\mathrm{km}^{2}$.

\begin{tabular}{|c|c|c|c|c|c|c|c|c|c|c|}
\hline $\begin{array}{l}\text { Major dr: } \\
\text { Number }\end{array}$ & $\begin{array}{l}\text { nage basin } \\
\text { Name }\end{array}$ & $\begin{array}{r}\text { Total } \\
\text { area }\end{array}$ & $\begin{array}{r}\text { Glacierized } \\
\text { area }\end{array}$ & $\begin{array}{r}\text { Percent } \\
\text { glacierized }\end{array}$ & $\begin{array}{r}\text { Comparable } \\
\text { glacier area }\end{array}$ & $\begin{array}{r}\text { Percent area } \\
\text { change }\end{array}$ & $\begin{array}{r}\text { \# of } \\
\text { glacier } \\
\text { units }\end{array}$ & $\begin{array}{r}\text { \# of unique 5-digit } \\
\text { Ids (excluding } \\
\text { snow patches) }\end{array}$ & $\begin{array}{r}\text { \# of } \\
\text { snowpatches }\end{array}$ & $\begin{array}{r}\text { Snowpatch } \\
\text { area }\end{array}$ \\
\hline \multirow{2}{*}{11} & \multirow{2}{*}{ Spitsbergen SE } & 4211 & 3003 & 71 & 2997 & \multirow{2}{*}{-3} & \multirow[t]{2}{*}{90} & 55 & 2 & 1 \\
\hline & & 4382 & 3102 & 71 & 3082 & & & 54 & 60 & 17 \\
\hline \multirow{2}{*}{12} & \multirow{2}{*}{ Spitsbergen $\mathrm{S}$} & 3106 & 1971 & 63 & 1965 & \multirow{2}{*}{-10} & \multirow[t]{2}{*}{86} & 51 & 6 & 3 \\
\hline & & 3242 & 2207 & 68 & 2186 & & & 44 & 52 & 21 \\
\hline \multirow{2}{*}{13} & \multirow{2}{*}{ Bellsund } & 5473 & 2212 & 40 & 2180 & \multirow{2}{*}{-13} & \multirow[t]{2}{*}{307} & 184 & 43 & 14 \\
\hline & & 5416 & 2580 & 48 & 2512 & & & 168 & 168 & 68 \\
\hline \multirow{2}{*}{14} & \multirow{2}{*}{ Isfjorden } & 7039 & 2431 & 35 & 2418 & \multirow{2}{*}{-15} & \multirow[t]{2}{*}{300} & 198 & 20 & 9 \\
\hline & & 7309 & 2930 & 40 & 2852 & & & 190 & 215 & 79 \\
\hline \multirow{2}{*}{15} & Snitchergen NW & 5362 & 3138 & 59 & 3113 & & 238 & 153 & 39 & 9 \\
\hline & Spitsbergen NW & 5443 & 3263 & 60 & 3226 & -3 & & 131 & 97 & 37 \\
\hline 16 & Wood_/ Wiidefiorden & 7349 & 2959 & 40 & 2909 & & 338 & 215 & 65 & 31 \\
\hline 10 & Wood-I Wijdefjorden & 7597 & 3249 & 43 & 3128 & -7 & & 207 & 174 & 69 \\
\hline 17 & Snitshergen NF & 5671 & 4415 & 78 & 4390 & -3 & 96 & 43 & 21 & 9 \\
\hline 17 & Spitsbergen NE & 5844 & 4530 & 78 & 4519 & -3 & & 41 & 29 & 10 \\
\hline 21 & Nordaustlandet SF & 5004 & 4517 & 90 & 4515 & & 19 & 14 & 1 & 3 \\
\hline 21 & Nordaustlandet SE & 5194 & 4783 & 92 & 4779 & & & 14 & 16 & 4 \\
\hline & & 3069 & 2491 & 81 & 2491 & & 19 & 16 & 0 & 0 \\
\hline 22 & Nordaustlandet W & 2993 & 2624 & 88 & 2615 & -5 & & 18 & 14 & 8 \\
\hline 23 & Nordaustlandet NW & 1738 & 736 & 42 & 733 & & 16 & 12 & 3 & 3 \\
\hline 23 & Nordaustlandet NW & 1836 & 780 & 42 & 751 & & & 15 & 92 & 21 \\
\hline 24 & Nordaustlandet N & 1637 & 747 & 46 & 746 & -6 & 22 & 16 & 2 & 1 \\
\hline 24 & Nordaustrandel iv & 1959 & 796 & 41 & 790 & -6 & & 17 & 12 & 4 \\
\hline 25 & Nordaustlandet NE & 2949 & 2219 & 75 & 2219 & & 13 & 10 & $\mathbf{0}$ & $\mathbf{0}$ \\
\hline 25 & Nordaustlandet NE & 3015 & 2276 & 75 & 2275 & & & 10 & 2 & 1 \\
\hline 31 & Fdgeøva & 5023 & 1785 & 36 & 1782 & & 109 & 94 & 7 & 3 \\
\hline 31 & Eageøуа & 5160 & 2198 & 43 & 2160 & & & 97 & 109 & 28 \\
\hline 32 & Barentsøya & 1274 & 504 & 40 & 504 & & 14 & 12 & 1 & $\mathbf{0}$ \\
\hline 32 & Barentsøya & 1298 & 610 & 47 & 582 & & & 15 & 124 & 24 \\
\hline 51 & Kvitøva & 657 & 647 & 99 & 647 & & 1 & 1 & 0 & $\mathbf{0}$ \\
\hline 31 & Kvitøya & 710 & 705 & 99 & 705 & & & 1 & 0 & 0 \\
\hline Sum of $C$ & $\mathbf{I}_{00}($ this study $)$ & 59562 & 33775 & 57 & 33608 & & 1668 & 1074 & 210 & 85 \\
\hline Sum of $\mathrm{H}$ & 3 (Hagen et al., 1993) & 61398 & 36633 & 60 & 36161 & & & 1022 & 1164 & 390 \\
\hline
\end{tabular}

Spitsbergen (Fig. 6), which together drain about $62 \%$ of the Spitsbergen glacierized area. The main tidewater drainage occurs off the eastern and western coastline of Spitsbergen and in Hornsund, Van Keulenfjord, Kongsfjord and Krossfjord.

\subsection{Comparison of complete glacier inventories (H93 vs. GI oos $_{\text {) }}$}

This section describes the differences between the only two fully complete glacier inventories of Svalbard, namely $\mathrm{H} 93$ and $\mathrm{GI}_{00 \mathrm{~s}}$. The comparison is complicated by both the varying time spans from which they were derived (Fig. 1) and the lack of raw H93 outlines to control that the upper glacier boundaries are consistent between the inventories. H93 contains 1022 individually labeled glaciers and 1164 non-labeled snow/ice masses less than $1 \mathrm{~km}^{2}$ totaling $36633 \mathrm{~km}^{2}$, or $60 \%$ of the archipelago's land area (Table 2), while $\mathrm{GI}_{00 \text { s }}$ contains 1668 individual glacier area polygons, or $\sim 57 \%$ of the archipelago land area. $\mathrm{GI}_{00 \text { s }}$ contain more individual units (polygons) due both to glacier retreat and separation, as well as our identification of distinct glacier flow units in glaciers previously classified by a single ID. Thus, $\mathrm{GI}_{00 \mathrm{~s}}$ glaciers are combined to their parent single 5digit integer ID for comparisons. $\mathrm{GI}_{00 \mathrm{~s}}$ contain an additional 52 smaller glaciers not formally identified in H93; these we have defined with 5-digit integer IDs that continue from the highest glacier number in each secondary drainage basin. Note that they do not follow the standard counter-clockwise identification sequence of $\mathrm{H} 93$.

In terms of snow patches, $\mathrm{GI}_{00 \text { s }}$ contains roughly a quarter of the number and area of snow patches as H93. There existed a large number of thin snow polygons in the NPI historic maps. These are due to local topographic depressions (i.e. gullies, trenches, chutes) that often remain snow-filled 
Table 3. List and description of attributes available for each glacier inventory.

\begin{tabular}{|c|c|c|c|c|}
\hline Attribute & Explanation & $\mathrm{GI}_{\text {old }}$ & $\mathrm{GI}_{90}$ & $\mathrm{GI}_{00 \mathrm{~s}}$ \\
\hline NAME & Glacier name & $\mathrm{X}$ & $\mathrm{X}$ & $X$ \\
\hline ID & Local identification code & $\mathrm{X}$ & $\mathrm{X}$ & $\mathrm{X}$ \\
\hline YEAR & Year of the outline & $\mathrm{X}$ & $\mathrm{X}$ & $\mathrm{X}$ \\
\hline DAY and MONTH & Specific date of outline & $\mathrm{X}$ & $\mathrm{X}$ & $\mathrm{X}$ \\
\hline SOURCE & Data source (i.e. aerial or satellite images) & $X$ & $\mathrm{X}$ & $X$ \\
\hline SATELLITE ID & Satellite ID (if available) & & & $X$ \\
\hline CENTROID X & $\mathrm{X}$ coordinate of the centroid of the polygon & $\mathrm{X}$ & $\mathrm{X}$ & $X$ \\
\hline CENTROID Y & Y coordinate of the centroid of the polygon & $\mathrm{X}$ & $X$ & $X$ \\
\hline TIDEWATER & Boolean variable: $1=$ tidewater, $0=$ land-terminating & $\mathrm{X}$ & $\mathrm{X}$ & $\mathrm{X}$ \\
\hline AREA & Area of glacier outline & $\mathrm{X}$ & $\mathrm{X}$ & $\mathrm{X}$ \\
\hline PERIMETER & Perimeter of glacier outline & $\mathrm{X}$ & $\mathrm{X}$ & $\mathrm{X}$ \\
\hline NUMBER OF CENTERLINES & Number of centerlines & & & $X$ \\
\hline CENTERLINE LENGTH & Centerline length (estimated as maximum length if multiple centerlines) & $X$ & $\mathrm{X}$ & $\mathrm{X}$ \\
\hline FRONT WIDTH & Width of the glacier tongue & $X$ & $\mathrm{X}$ & $\mathrm{X}$ \\
\hline X GLIMS ID & $\mathrm{X}$ coordinate used for GLIMS Ids & & & $\mathrm{X}$ \\
\hline Y GLIMS ID & Y coordinate used for GLIMS Ids & & & $\mathrm{X}$ \\
\hline GLIMS ID & GLIMS ID & & & $\mathrm{X}$ \\
\hline MEDIAN Z & Median elevation & & & $\mathrm{X}$ \\
\hline MINIMUM Z & Minimum elevation & & & $\mathrm{X}$ \\
\hline MAXIMUM Z & Maximum elevation & & & $\mathrm{X}$ \\
\hline STANDARD DEVIATION Z & Standard deviation of elevation & & & $\mathrm{X}$ \\
\hline SKEWNESS Z & Skewness of the elevation distribution & & & $\mathrm{X}$ \\
\hline MEAN SLOPE & Mean slope & & & $\mathrm{X}$ \\
\hline MEAN ASPECT & Mean aspect & & & $\mathrm{X}$ \\
\hline HYPSOMETRY & Area elevation distribution in 50-meter elevation bins & & & $\mathrm{X}$ \\
\hline DEM SOURCE & Source for elevation statistics and hypsometry & & & $\mathrm{X}$ \\
\hline
\end{tabular}

in mid- to late summer, and thus were liable to be identified by cartographers as "glacier" in aerial and satellite images. We do not consider these polygons as glaciers and they are not maintained in our GI inventories; however, they are most likely included in the H93 count of glaciers/snow patches $<1 \mathrm{~km}^{2}$ and probably are the reason behind the differences in snowpatches between the inventories.

The difference between comparable areas of H93 and $\mathrm{GI}_{00 \text { s }}$ reveals a glacierized area loss of $7 \%$ (Table 2 ), or about $80 \mathrm{~km}^{2} \mathrm{a}^{-1}$ for the average $32 \mathrm{yr}$ time span between the inventories. Area changes are computed at the primary and secondary drainage basin scale (Table 2 and Fig. 6b). This reduces random uncertainties from individual glacier divides and possibly misclassifications (see Sect. 4.4). The smallest relative changes $(-2$ to $-5 \%)$ have occurred in Nordaustlandet and the largest $(-13$ to $-17 \%)$ in central Spitsbergen, a region dominated by small glaciers, and Barentsøya/Edgeøya (Table 2). These patterns naturally reflect glacier area itself (Figs. 4b and 6b) as described in many other glacier inventory studies (Kääb et al., 2002; Andreassen et al., 2008; Racoviteanu et al., 2008; Bolch et al., 2010; Le Bris et al., 2011) and further complicate spatial and temporal change analysis of inventory data.

\subsection{Comparison of multi-temporal glacier inventories ( GI $_{\text {old }}$ vs. GI $\mathbf{I}_{90}$ vs. GI $\mathbf{I}_{00 \mathrm{~s}}$ )}

The digital glacier inventories are available for three different times (Fig. 1), with 946 consistent glaciers ( $~ 30 \%$ of the total Svalbard glacierized area) located in southern and western Spitsbergen. This permits analysis of two time periods, from $\mathrm{GI}_{\text {old }}$ to $\mathrm{GI}_{90}$ (Epoch 1, which is $\sim 50 \mathrm{yr}$ on average) and from $\mathrm{GI}_{90}$ to $\mathrm{GI}_{00 \mathrm{~s}}$ (Epoch 2, which is $\sim 17 \mathrm{yr}$ on average). In sum, these glaciers lost $\sim 31 \mathrm{~km}^{2} \mathrm{a}^{-1}\left(0.26 \% \mathrm{a}^{-1}\right)$ during Epoch 1 and $\sim 24 \mathrm{~km}^{2} \mathrm{a}^{-1}\left(0.23 \% \mathrm{a}^{-1}\right)$ during Epoch 2 . In the following analysis, the sample population is limited to glaciers larger than $2 \mathrm{~km}^{2}$ (406 glaciers) since smaller glaciers are more prone to interpretation errors related to seasonal snow.

Figure 7a shows centerline length changes and area/width length changes (calculated according to Sect. 3.4). On average, area/width retreat rates are $\sim 10 \mathrm{ma}^{-1}$ larger than centerline retreat rates. This is expected since the area/width length changes are an integrated change that also include lateral losses, while the centerline length changes are dependent upon one measurement taken along the centerline at the glacier front.

The distribution of length change rates (as estimated using the area/width approach) in both epochs is shown in 

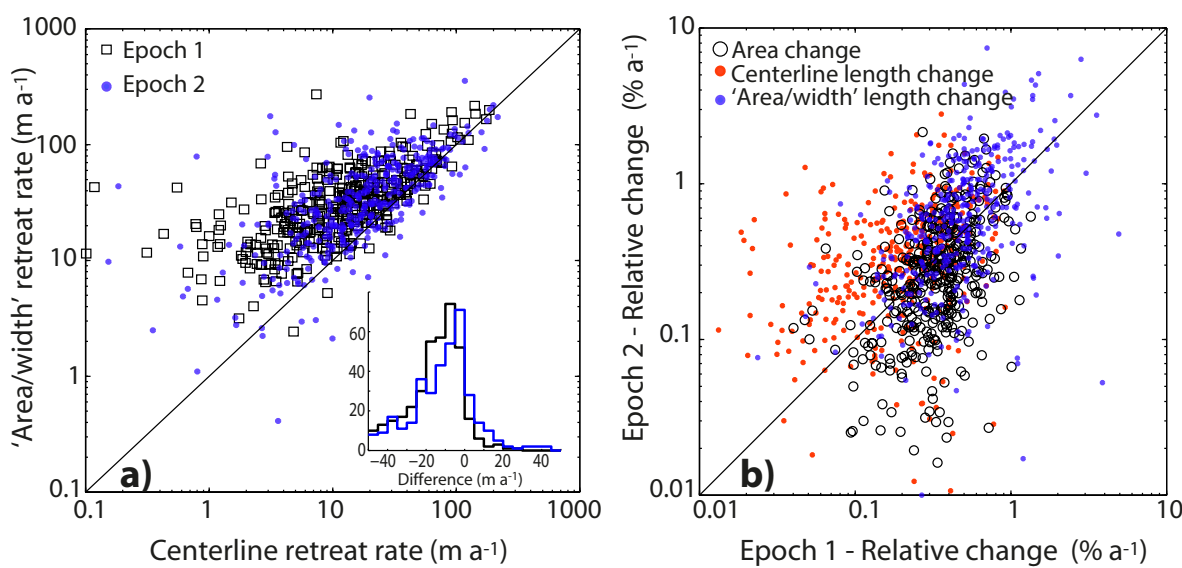

Fig. 7. (a) Temporal mean retreat rates for Epoch 1 and 2, as estimated from the centerline differences and by the area change divided by tongue width ("area/width"). The inset shows the histogram of differences between the two retreat rate estimates. The "area/width" retreat rates are larger than the centerline due to both incorporation of lateral losses in the area/width retreat rate estimate and a lack of representative retreat sampling of the centerline. (b) Relative changes during Epoch 1 and Epoch 2 for area changes, centerline length changes and the "area/width" length changes.

Fig. 8. Length change rates generally vary between 0 and $-150 \mathrm{ma}^{-1}$, with an average of $\sim-40 \mathrm{~m} \mathrm{a}^{-1}$ and median of $-30 \mathrm{~m} \mathrm{a}^{-1}$ for both epochs. Larger extreme retreat rates exist $\left( \pm 150-350 \mathrm{ma}^{-1}\right)$, in most cases related to surge behavior. It seems the retreat of glaciers has increased, as is apparent in the shift in the distribution of retreat rates towards more negative values in Epoch 2. This is mostly apparent in central and southern Spitsbergen, as compared to northwest Spitsbergen, where average length change rates have remained similar (or even less negative) between the epochs (Fig. 8).

Comparisons between the relative changes of Epoch 1 and Epoch 2 for the area and length changes display varying patterns (Fig. 7b). Relative length changes are mainly larger for Epoch 2 than Epoch 1. Similarly to the absolute differences described above (Fig. 7a), relative centerline changes are smaller and vary more than relative area/width length changes. Relative area changes show greater scatter, with many glaciers experiencing larger relative changes during Epoch 1 than Epoch 2. This pattern is opposite that of relative length changes (both centerline and area/width length changes) and is at least partially a result of lateral glacier wastage, which was larger in Epoch 1 than Epoch 2. Nevertheless, all relative changes are dependent upon the original size of the parameter (length or area), and thus spatial and temporal comparisons are hampered by this dependence, which results in heteroscedastic distributions with glacier size (see e.g. Kääb et al., 2002; Bolch et al., 2010).

\subsection{Accuracy}

Errors in the glacier outlines depend on the images used to delineate glaciers (i.e. their resolution and quality) and sky and ground conditions, and the analyst's ability to digitize and interpret the imagery. Errors of the latter kind arise both from the manual interpretation of glacier-land boundaries and from the uncertainty of locating hydrological divides of interconnected ice fields (i.e. based upon surface topography). Errors in ice field divides are related to the accuracy of the DEM and to the hydrological flow directions derived from it when using automated hydrological GIS algorithms. Interpretation uncertainty may arise, for example, in cases where debris or lateral moraines obscure the glacier outlines, or where seasonal snow in the imagery covers the glacier edge. A manual digitization experiment (Paul et al., 2013) with 20 participants on 24 glaciers resulted in area uncertainties (expressed as a relative difference) ranging between 2 and $30 \%$; the largest errors came from sections of glaciers with heavy debris cover. Manual digitization error was found to be on the order of 1-3 pixels at any vertex; relative errors were typically better than $5 \%$, varying with glacier size and conditions (i.e. debris cover) (Paul et al., 2013). For our digital datasets, we expect errors of this magnitude but also some degree of spatial variability in the uncertainty since, for example, central and north-central areas are less glacierized (i.e. less than $40 \%$ in Fig. 4b) and have larger amounts of debris cover and/or ice-cored moraines.

Glacier outlines for H93 are not digitally available, but they are based on many of the same topographic maps as $\mathrm{GI}_{\text {old }}$ from which we have derived glacier divides independently using historic and recent DEMs (Sect. 3). Glacier areas based on data from the same year can be compared to estimate an uncertainty related to glacier division and manual delineation. There are 170 common glacier units in H93 and $\mathrm{GI}_{\text {old }}$; their relative differences approximate a Student's $t$ distribution (i.e. heavier tails) with a standard deviation of about $8 \%$, while the standard deviation of the Gaussian distribution fit is $20 \%$ (Fig. 9). The heavier tails of this relative error distribution result from gross differences in determining 

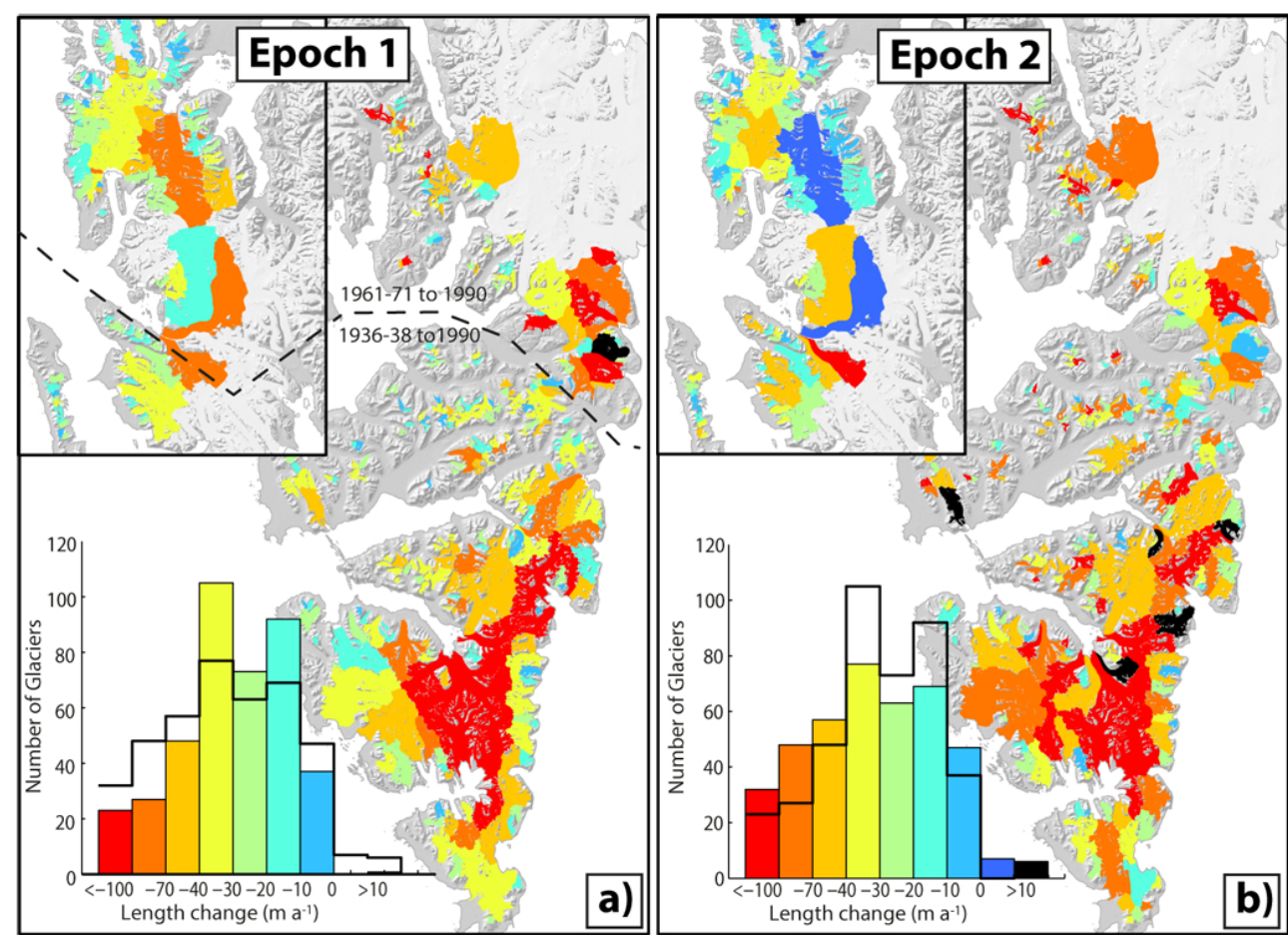

Fig. 8. Average length change rates calculated using the area/width method between (a) $\mathrm{GI}_{\mathrm{old}}$ and $\mathrm{GI}_{90}$ and (b) $\mathrm{GI}_{90}$ and $\mathrm{GI}_{00 \mathrm{~s}}$. The inset map is a section of northwest Spitsbergen. The histogram insets show the number of glaciers for each color used in the map. The straight bar line in the histograms are of the alternate epoch for comparison. The distribution of Epoch 2 length changes is more negative than that of Epoch 1.

drainage divides or from the inclusion or exclusion of lateral moraines, which impacts the relative error more heavily than the smaller random errors introduced in digitization (as described in Paul et al., 2013).

We define the individual glacier area error as the $95 \%$ confidence interval of the Student $t$ distribution, about $16 \%$, but note that the relative error is dependent upon glacier size as well (Kääb et al., 2002; Bolch et al., 2010; Paul et al., 2013), with smaller glaciers having larger relative errors. The bulk of the glaciers have errors less than $5 \%$, similar to other inventories (Paul et al., 2002; Bolch et al., 2010; Gjermundsen et al., 2011; Rastner et al., 2012). The error may be largely systematic at the individual glacier scale but is random at the regional or inventory-wide scale; i.e. the uncertainty of the drainage divides is cancelled. A rough conservative estimate for the error of the entire glacierized area of Svalbard is 1$2 \%\left(\sim 500 \mathrm{~km}^{2}\right)$.

Finally, we simulate a $16 \%$ error on the area changes and on the glacier tongue widths to estimate a sensitivity to and the precision of our area/width length changes. For the entire population of changes from Epoch 2, the residuals between the original length changes and those calculated with $16 \%$ differences in the area changes and widths separately result in a error distribution approximated by a Student $t$ with $95 \%$ of the residuals contained within $\pm 10 \mathrm{ma}^{-1}$. Combining both uncertainties from area changes and glacier tongue width es-

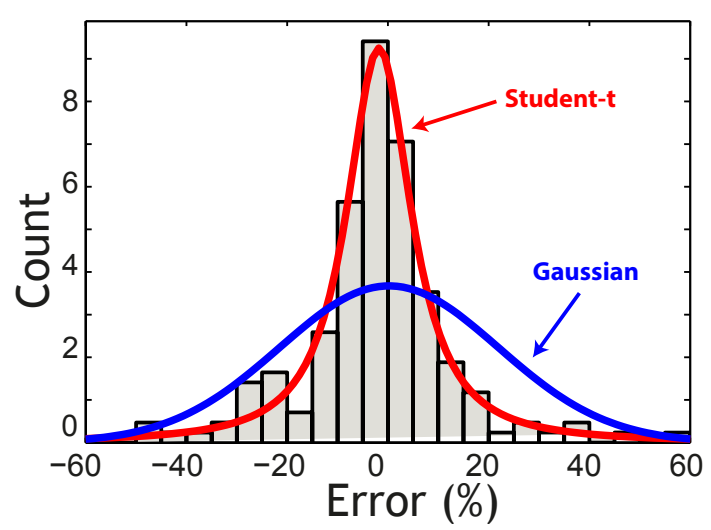

Fig. 9. Distribution of area errors between $\mathrm{H} 93$ and $\mathrm{GI}_{\mathrm{old}}$ for all glaciers mapped in the same year, as a percent of the glacier area showing Gaussian and Student $t$ distributions fit to the data. The heavier tails of the Student $t$ distribution reflect the effect of larger blunders on glacier outlines, presumably due to varying hydrological divides and debris cover/lateral moraine delineation between the area estimates. 
timates by standard error propagation (root sum of squares) results in an error of $14 \mathrm{ma}^{-1}$. About $80 \%$ of the observed length change rates in Epoch 1 and 2 (Fig. 8) are above this uncertainty.

All of the change parameters are sensitive to bias induced by interpretation uncertainty. In particular, the decision whether to include or exclude lateral moraines within the glacier area needs to be consistent within multi-temporal inventories. In Svalbard, glacier ice may exist beneath these lateral moraines (F. Navarro and A. Martín-Español, personal communication, 2013). Our inventories exclude lateral moraines by adopting a visual definition for delineating glaciers based on spectral appearance. Without widespread ground truth information about ice below debris, it is not possible to quantify potential error introduced. In addition, the decision whether to include or exclude lateral moraines is subjective and dependent upon the purpose of the glacier area outline. In Svalbard, the retreat of glaciers commonly occurs at the front rather than the sides; accordingly exclusion of the lateral moraines seems appropriate for studies of glacier extent changes. Alternately, using glacier area for volume estimation may require their inclusion (Radić and Hock, 2010; Huss and Farinotti, 2012; Martín-Español et al., 2013).

\section{Discussion}

Our new glacier inventory of Svalbard, $\mathrm{GI}_{00 \mathrm{~s}}$, can be used to extract spatial data reflecting topography and climatology of the archipelago. Median glacier elevation (Fig. 5a) is a characteristic of an individual glacier's hypsometry that is highly correlated with the equilibrium line altitude, or ELA (Braithwaite and Raper, 2009). The median elevation has been used for developing concepts of "glaciation limits" and proxies for the long-term ELA, the patterns of which suggest an inverse relation to the precipitation regime (Østrem, 1966; Schiefer et al., 2008). In Svalbard, spatial patterns of median glacier elevation have previously been used to infer spatial variability of the ELA (Hagen et al., 2003) and precipitation (Hisdal, 1985; Hagen et al., 1993; Winther et al., 1998; Sand et al., 2003). In central Spitsbergen, the spatial patterns of the median elevation match closely the mapped 1990 late summer snow line (a proxy for the ELA) distribution (Humlum, 2002). On Austfonna, snow depth variability shows a clear northwest-southeast gradient (Taurisano et al., 2007; Dunse et al., 2009) due to the predominance of precipitation coming from the Barents Sea (Schuler et al., 2007). This is reflected in lower median glacier elevations towards the southeast and higher towards the northwest (Fig. 5a). Spatial patterns of median glacier elevation similarly reflect the annual total number of melt days and summer melt onset as estimated from QuikSCAT scatterometry (Rotschky et al., 2011). The spatial patterns of median elevation over the archipelago reflect the local degree of glaciation, which is dependent upon both the terrain and the long-term regional climatological patterns that result in spatial variations of accumulation and ablation (mass balance) over the terrain surface. Higher glacier median elevations occur in the central drier regions of Spitsbergen and correspond to areas that experience lower average annual melt days, which could imply lower mass turnover. Moreover, these areas have lower percent glaciation and larger number of glaciers in the inventory (Fig. 4).

A glacier inventory represents a snapshot of the glacier geometrical extent, typically at a single point in time. Our glacier inventories are generally not a single point in time but cover a range of times, though each glacier outline has a distinct time stamp. Comparing multiple glacier inventories through time allows investigation of changes in some of the basic glacier geometry parameters. Changes in glacier area and length reflect the glacier's total response (Oerlemans, 2001). At smaller regional scales, area and length changes of individual glaciers manifest themselves differently to the presumably more or less uniform driving climate signal, due to variable glacier response times. Glacier response time is proportional to thickness and inversely proportional to the ablation rate at the terminus (e.g. Jóhannesson et al., 1989), such that front positions of small thin glaciers respond more quickly to the same climate change signal. Above a critical glacier size (i.e. larger glaciers) and holding all mass balance gradients similar, theory and modeling experiments predict a decreasing response time, with increasing glacier size resulting from the dynamic controls on response time (Bahr et al., 1998; Pfeffer et al., 1998). Estimated response times for Svalbard glaciers are in the range of decades to centuries, implying that observed front position changes still contain signals from earlier climatic events - especially true for Epoch 1. Epoch 2 changes may reflect climate changes during both Epoch 1 and Epoch 2. In Svalbard, the frequent surging behavior of many Svalbard glaciers (Lefauconnier and Hagen, 1991; Hagen et al., 1993; Hamilton and Dowdeswell, 1996; Jiskoot et al., 2000; Sund et al., 2009) complicates reconstructions of past climate from change records (as in Oerlemans, 2005). Finally, since each inventory represents a single glacier snapshot, the variation in temporal separation between inventories (epoch length), and its relation with the timing of each individual glaciers response will influence the observed average change rates. Enhanced interpretation of these changes may be possible with the inclusion of an accurate surge glacier inventory. This was not completed for this study due to insecurities in defining exactly which glaciers have fully surged or only partially surged (Sund et al., 2009) especially over the decadal time period of this study where glaciers that have surged may not be visible in the area changes given the long time span between the inventories. Future work should focus on generating such an inventory.

Figure 10 shows the difference between area/width retreat rates of Epoch 1 and Epoch 2 for the sample of 392 glaciers larger than $2 \mathrm{~km}^{2}$ that have retreated in both epochs. About 


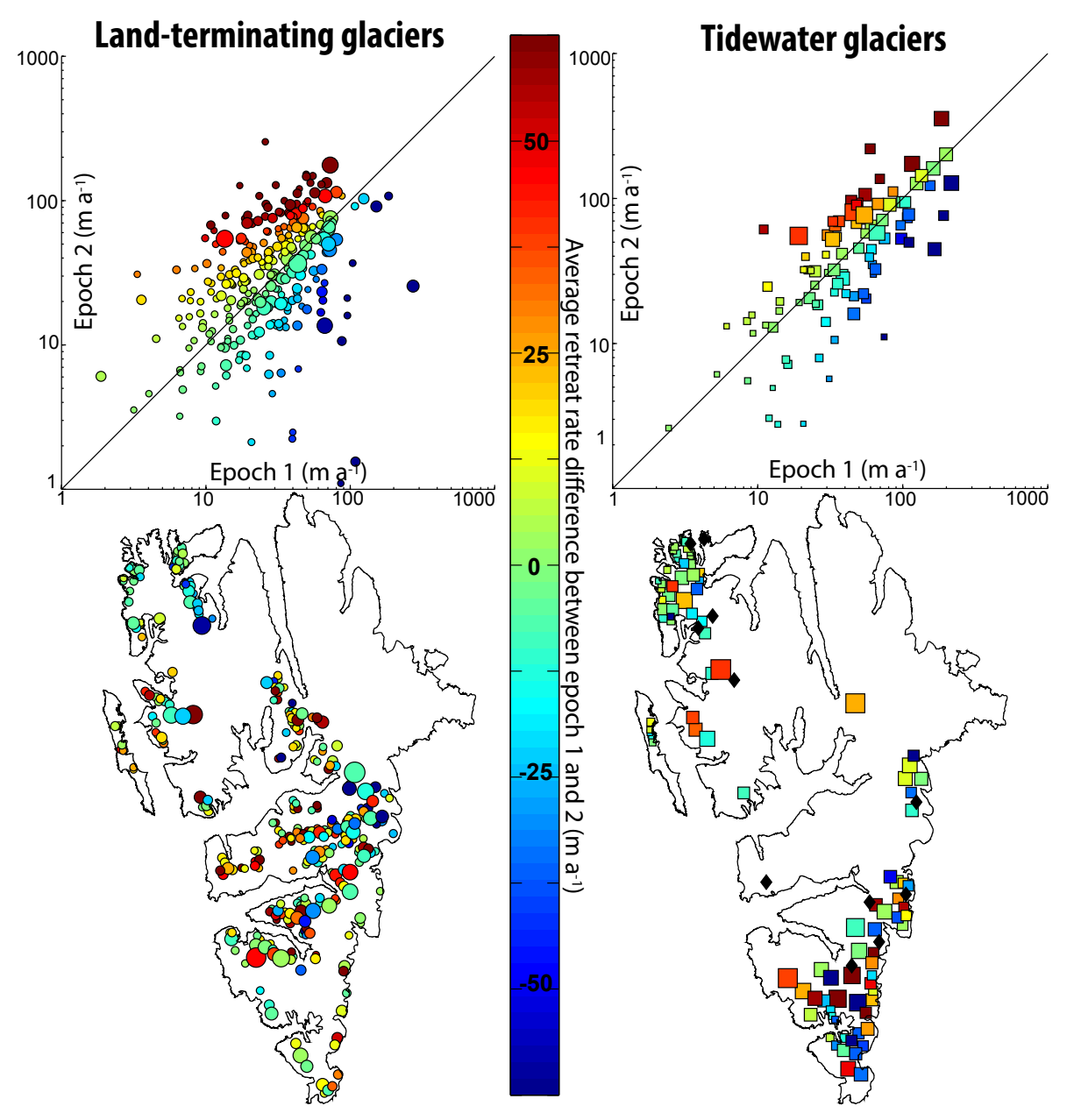

Fig. 10. Annual average length changes calculated using the "area/width" method for land-terminating (left) and tidewater (right) glaciers for Epoch 1 vs. Epoch 2. Colors represent the difference in average retreat rates between the epochs. Black diamonds are glaciers that have advanced in either Epoch 1 or 2. Symbols in the maps (bottom) are identical to those in the scatter plots (top). In the scatter plots, points below the 1: 1 line are glaciers that have experienced smaller retreat rates in Epoch 2 (blue), while points above the line are glaciers that have experienced greater retreat in Epoch 2 (red). Note the log scale of the scatter plot and linear color scale in the difference of average retreat rates. The size of the symbol is a log scale of the glacier size.

$60 \%$ of the differenced retreat rates are greater than the $95 \%$ confidence interval of $10 \mathrm{ma}^{-1}$ (see Sect. 4.4). For the entire sample and the significant subsample, $\sim 60 \%$ of the glaciers have experienced larger retreat rates in Epoch 2, apparent as a shift in the histograms between the two epoch-averaged retreat rates (Fig. 8). The spatial patterns of Fig. 10 suggest a potential regional trend with greater retreat in Epoch 2 in southern Spitsbergen and less so in northwest Spitsbergen. Moreover, slight clustering or spatial autocorrelation in the retreat rate changes between the epochs is present. This may reflect the geometrical similarity between neighboring glaciers that is dictated by the topography and the more or less uniform driving climate signal. On top of the apparent clustering, larger outliers are present, with some neighboring glaciers having opposing (either positive or negative) differenced retreat rates. These local outliers represent variability in the individual glacier responses to the driving climate and/or the effect of past and present surge glaciers and their surge history in relation to the timing of the inventories. Combination with additional parameters such as geodetic volume changes (e.g. Nuth et al., 2007), estimated glacier volumes and thicknesses or terminus mass balance rates (Haeberli and Hoelzle, 1995; Hoelzle et al., 2007) will aid interpretations related to response times and climate.

The most common parameter for inventory change in the literature is relative area change which is dependent on the glacier and terrain geometry (e.g. size, individual glacier tongue shape, bed topography etc.). Smaller glaciers often have larger relative changes, such that the variability with glacier size is heteroscedastic. This complicates statistical and spatial analysis of relative changes. To reduce the area dependency, we estimate length changes using 2 approaches 
(Sect. 3.4). Area/width length changes are larger than the centerline length changes (Fig. 7a) as they integrate the entire front position change (including lateral changes), while centerline changes are one single measurement of the front. The area/width method minimizes area-related errors from uncertain upper glacier boundaries by limiting the analysis to area change below the median glacier elevation and may be fully automated allowing easy retrieval from repeat inventories.

Using the entire sample of glaciers that exist consistently in $\mathrm{GI}_{\mathrm{old}}, \mathrm{GI}_{90}$ and $\mathrm{GI}_{00 \mathrm{~s}}$, the total area change rates and relative area change rates are $22 \%$ smaller in Epoch 2 $\left(-24 \mathrm{~km}^{2} \mathrm{a}^{-1}, 0.23 \% \mathrm{a}^{-1}\right)$ than in Epoch $1\left(-31 \mathrm{~km}^{2} \mathrm{a}^{-1}\right.$, $0.26 \% \mathrm{a}^{-1}$ ). Alternately, summing the area/width (centerline) length changes for all glaciers results in 14 (30) \% more negative length changes during Epoch $2(-29.5(-15.3) \mathrm{km}$ $\left.\mathrm{a}^{-1}\right)$ as compared to Epoch $1\left(-25.6(-11.9) \mathrm{km} \mathrm{a}^{-1}\right)$. Thus, while area change rates were larger in Epoch 1, the length change rates were larger in Epoch 2, which is similarly reflected in Fig. 7b. The total summed change rates of glacier tongue width during Epoch 1 is $-2.2 \mathrm{kma}^{-1}$ as opposed to $-1.4 \mathrm{~km} \mathrm{a}^{-1}$ for Epoch 2. General reduction in glacier area loss rates in Epoch 2 is probably a geometrical effect of decreased lateral wastage of the glacier tongues, despite the faster average retreat rates experienced in Epoch 2.

\section{Conclusions}

This study describes the creation of a consistent multitemporal digital glacier inventory of the Svalbard archipelago, based on the structure of the previous inventory (Hagen et al., 1993). Our new digital inventory is based on historic data that are available digitally and then progressively updated through time to maintain consistency between the glacier outlines. This required modification of the identification system already in place (WGMS, 1989; Hagen et al., 1993) for glaciers that have retreated and separated. Moreover, the newest inventory also includes snowpatches and glacierets that are less than $1 \mathrm{~km}^{2}$ as identified in available cloud-free SPOT, ASTER and Landsat images. $\mathrm{GI}_{00 \text { s }}$, the present digital inventory, coheres to both GLIMS and WGI standards (with slight modifications) and has been incorporated into the Randolph Glacier Inventory (Arendt et al., 2012) and the GLIMS database. The inventories may also be downloaded from the Norwegian Polar Institute data archive (http://data.npolar.no/dataset/ 89f430f8-862f-11e2-8036-005056ad0004).

In total, the $\mathrm{GI}_{00 \mathrm{~s}}$ inventory of glaciers in Svalbard contains 1668 individual glacier units, for a total glacierized area of $33775 \mathrm{~km}^{2}$, or $\sim 57 \%$ of the archipelago. About $60 \%$ of the glacierized area is on Spitsbergen and $40 \%$ on the island to the east-northeast. Between 168 and 197 tidewater glaciers (depending on how a single tidewater glacier is defined) drain $68 \%$ of the glacierized area through a summed glacier terminus width of about $740 \mathrm{~km}$. The glacierized area has decreased by an average of $\sim 80 \mathrm{~km}^{2} \mathrm{a}^{-1}$ over the past $\sim 30 \mathrm{yr}$, a reduction of $7 \%$. For a sample of $\sim 400$ glaciers in south and west Spitsbergen, glacier retreat was greater after 1990 (Epoch 2), while area change rates were greater in the decades before 1990 (Epoch 1), corresponding to more lateral wastage in the early period.

We suggest that reducing the dimensions of area change to a length scale may provide a more useful parameter for spatio-temporal analysis of change signals. This falls in line with previous investigations (Raup et al., 2009) and may enhance the use and incorporation of glacier inventory changes, for example, into numerical models (e.g. Oerlemans, 1997; Vieli et al., 2001; Nick et al., 2009) and/or temperature reconstructions (Oerlemans, 2005; Leclercq and Oerlemans, 2012). The spatio-temporal variability of the length change rates suggests response time variation that requires further investigation. With increased accuracy and capability to automatically generate glacier inventories at higher temporal resolutions using satellite data, the generation of repeat glacier inventory changes in the form of area, tongue width and length changes will become an important observational dataset for future glacier-climate studies.

\section{Appendix A}

\section{ASTER GDEM pre-processing and assessment}

The ASTER GDEM Version 2 is a merged composite of multi-temporal DEMs from individual ASTER stereo image pairs. As with version 1 , version 2 contains a quality mask that indicates the number of images used for determining each pixel elevation. Individual DEMs are automatically generated following Fujisada et al. (2005), and then merged by averaging the data stack at similar locations after filtering pixels that are $40 \mathrm{~m}$ higher than the mean (Fujisada et al., 2012). One improvement to version 1 is an improved resolution resulting from a smaller matching template in the original parallax determination of the DEM generation (Tachikawa et al., 2011). Version 2 displays a single distinct misalignment when compared to ICESat and SPOT-SPIRIT DEMs despite the apparent lack of co-registration during the DEM stacking process (Fujisada et al., 2012) and relatively good co-registration documented in the final validation report (Tachikawa et al., 2011).

On smooth, low-slope glacier surfaces, the GDEM Version 2 displays a bumpy appearance most predominant in the upper reaches of the glaciers (Fig. A1). This is an artifact of the merging of multiple (and multi-temporal) DEMs that have lower quality in the regions of less visible contrast. Visually, these artifacts seem to have a specific spatial frequency that we hypothesize may be characterized and removed in the spatial frequency domain through Fourier-based filtering methods. The original GDEM is first co-registered to ICESat (Nuth and Kääb, 2011). We then search for a common 

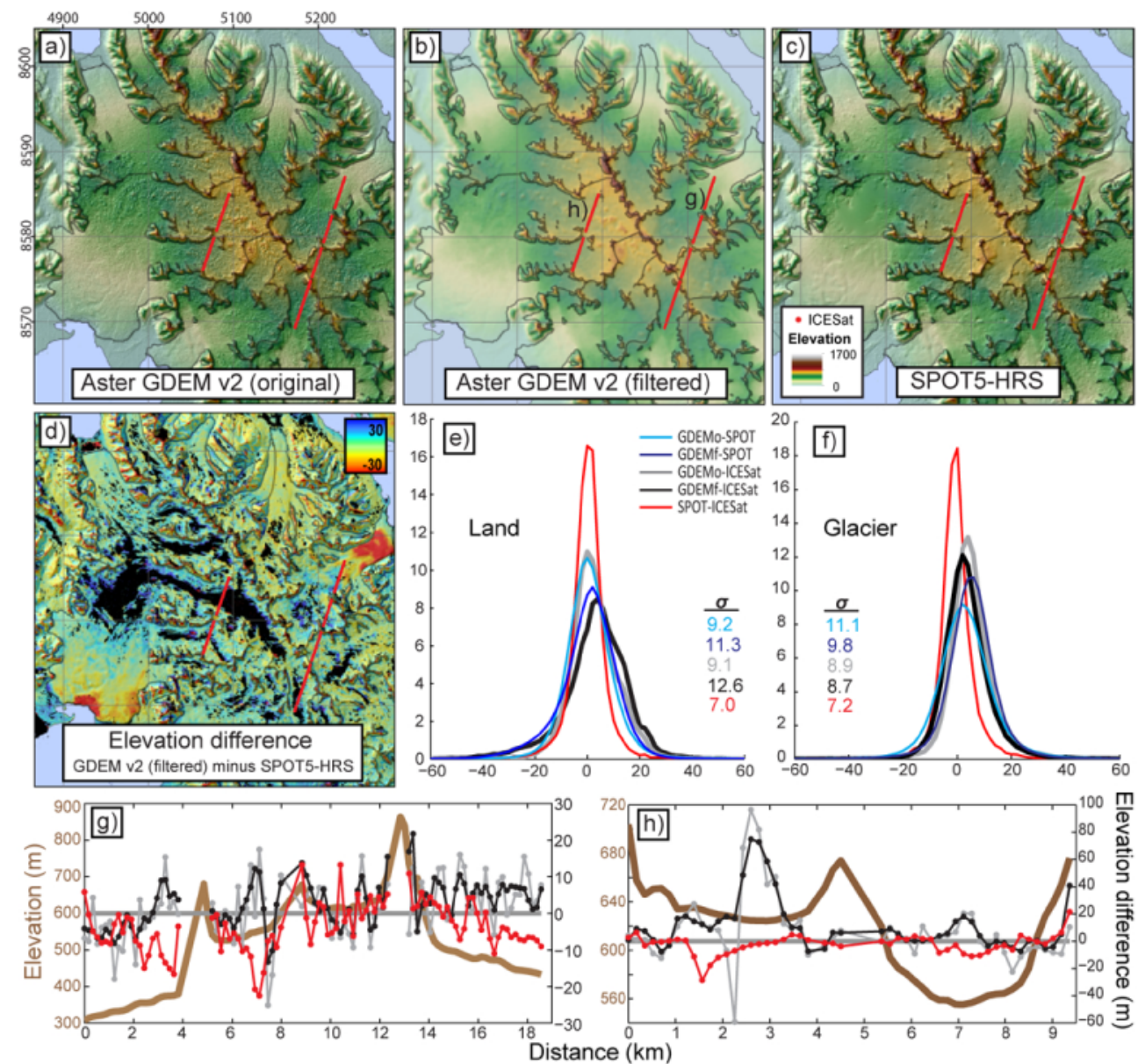

Fig. A1. (a) Hillshades draped by elevation for the original ASTER GDEM, (b) the Fourier-filtered GDEM, and (c) a 2008 SPOT5-HRS DEM. (d) The differences between the filtered GDEM and the SPOT DEM with the black areas containing correlations that are less than 40. (e) and (f) show normalized histograms ( $y$ axis as percentage of pixels) of elevation differences ( $x$ axis in meters) for land and glaciers, respectively, for the DEMs and ICESat. In the legend of (e), "GDEMo" and "GDEMf" are the original and filtered GDEM, respectively. (g) and (h) show two individual ICESat profiles over higher-elevation glacier regions (typical for low visible contrast areas) from 27 May 2005 and 19 March 2008, respectively, with their differences to the three DEMs. The thick brown line shows the topography, while the other colored lines correspond to the labels presented in (e).

frequency of the bumpy glacier surface seen in Fig. A1a. A single frequency of the artifacts was not practically determinable for use in a frequency stop filter due to the similarity of the artifacts with the natural glacier topographic fluctuations and the frequency of off-glacier terrain. Therefore, we choose to apply a standard low-pass filter in the frequency domain, using a Hanning window. The set of parameters (order and frequency cut-off) is chosen by minimizing the standard deviation of the glacier differences between the GDEM and ICESat. Post-filtered topography was not sensitive to small fluctuations in the parameters. The filtered GDEM (Fig. A1b) shows improvement over smooth glaciers (Fig. A1e) but resembles a downgraded (lower resolution) product over the rougher surrounding terrain (Fig. A1f). Most of the higher-frequency noise is removed (Fig. A1g), though the lower-frequency bumps remain, with maximum differences of up to 50-60 m (Fig. A1h). Therefore, our final post-processed GDEM is a compilation of the Fourierfiltered glacier surface with a median block filtered nonglacier surface.

Acknowledgements. We would like to thank the Norwegian Polar Institute mapping section for the generation and digitization of the historic and 1990 maps. Many thanks to T. Heid and K. Langley for helpful discussions and code for filtering the GDEM. The authors would like to thank T. James, M. Pelto and an anonymous reviewer for their thoughtful comments which improved the clarity and description of the inventories and changes between them. This study was supported by the European Space Agency (ESA) through the projects Glaciers_CCI (4000101778/10/I-AM) and Cryoclim, which is also supported by the Norwegian Space Centre. This publication is contribution number 28 of the Nordic Centre of Excellence SVALI, Stability and Variations of Arctic land Ice, funded 
by the Nordic Top-level Research Initiative. The SPOT5-HRS DEMs and orthophotos were obtained through the IPY-SPIRIT program (Korona et al., 2009) ${ }^{\circledR}$ CNES 2008 and SPOT Image 2008, all rights reserved. The ASTER L1B data were obtained within the framework of the Global Land Ice Measurements from Space project (GLIMS) through the online data pool at the NASA Land Processes Distributed Active Archive Center (LP DAAC), USGS/Earth Resources Observation and Science (EROS) Center, Sioux Falls, South Dakota. Landsat images are downloaded from http://glovis.usgs.gov/. NASA's ICESat GLAS data were obtained from NSIDC. The ASTER GDEM [v2] is a product of METI and NASA and was downloaded from the LPDAAC.

Author Contributions. J. Kohler, M. König and C. Nuth realized the design of the inventory. M. König, G. Moholdt, R. Petterson and C. Nuth contributed data to the inventory. A. von Deschwanden prepared submission of the inventory to the GLIMS database. J. Kohler, J. O. Hagen, A. Kääb and C. Nuth developed concepts to the study and methodologies. C. Nuth prepared the final data and wrote the original manuscript. All authors wrote and edited the final paper.

Edited by: J. L. Bamber

\section{References}

Ahlmann, H. W., Eriksson, B. E., Ångström, A., and Rosenbaum, L.: Scientific Results of the Swedish-Norwegian Arctic Expedition in the Summer of 1931, Part IV-VIII, Geogr. Ann., 15, 73216, http://www.jstor.org/stable/519460, 1933.

Andreassen, L. M., Paul, F., Kääb, A., and Hausberg, J. E.: Landsatderived glacier inventory for Jotunheimen, Norway, and deduced glacier changes since the 1930s, The Cryosphere, 2, 131-145, doi:10.5194/tc-2-131-2008, 2008.

Arendt, A., Bolch, T., Cogley, J., Gardner, A., Hagen, J.-O., Hock, R., Kaser, G., Pfeffer, W., Moholdt, G., Paul, F., Radic, V., Andreassen, L., Bajracharya, S., Beedle, M., Berthier, E., Bhambri, R., Bliss, A., Brown, I., Burgess, E., Burgess, D., Cawkwell, F., Chinn, T., Copland, L., Davies, B., Angelis, H. D., Dolgova, E., Filbert, K., Forester, R., Fountain, A., Frey, H., Giffen, B., Glasser, N., Gurney, S., Hagg, W., Hall, D., Haritashya, U., Hartmann, G., Helm, C., Herreid, S., Howat, I., Kapustin, G., Khromova, T., Kienholz, C., Koenig, M., Kohler, J., Kriegel, D., Kutuzov, S., Lavrentiev, I., LeBris, R., Lund, J., Manley, W., Mayer, C., Miles, E., Li, X., Menounos, B., Mercer, A., Moelg, N., Mool, P., Nosenko, G., Negrete, A., Nuth, C., Pettersson, R., Racoviteanu, A., Ranzi, R., Rastner, P., Rau, F., Raup, B., Rich, J., Rott, H., Schneider, C., Seliverstov, Y., Sharp, M., Sigurdsson, O., Stokes, C., Wheate, R., Winsvold, S., Wolken, G., Wyatt, F., and Zheltyhina, N.: Randolph Glacier Inventory [v2.0]: A Dataset of Global Glacier Outlines, Tech. rep., Global Land Ice Measurements from Space, 2012.

AST14DMO: On Demand Digital Elevation Model \& Registered Radiance at the Sensor - Orthorectified, Tech. rep., NASA Land Processes Distributed Active Archive Center (LP DAAC), USGS/Earth Resources Observation and Science (EROS) Center, Sioux Falls, South Dakota, 2010.

Bahr, D. B.: Width and length scaling of glaciers, J. Glaciol., 43, 557-562, 1997.
Bahr, D. B. and Radić, V.: Significant contribution to total mass from very small glaciers, The Cryosphere, 6, 763-770, doi:10.5194/tc-6-763-2012, 2012.

Bahr, D. B., Pfeffer, W. T., Sassolas, C., and Meier, M. F.: Response time of glaciers as a function of size and mass balance: 1 . Theory, J. Geophys. Res., 103, 9777-9782, doi:10.1029/98JB00507, 1998.

Blaszczyk, M., Jania, J. A., and Hagen, J. O.: Tidewater glaciers of Svalbard: Recent changes and estimates of calving fluxes, Pol. Polar Res., 30, 85-142, 2009.

Bolch, T., Menounos, B., and Wheate, R.: Landsat-based inventory of glaciers in western Canada, 1985-2005, Remote Sens. Environ., 114, 127-137, doi:10.1016/j.rse.2009.08.015, 2010.

Box, J. E. and Decker, D. T.: Greenland marine-terminating glacier area changes: 2000-2010, Ann. Glaciol., 52, 91-98, doi:10.3189/172756411799096312, 2011.

Braithwaite, R. and Raper, S.: Estimating equilibrium-line altitude (ELA) from glacier inventory data, Ann. Glaciol., 50, 127-132, doi:10.3189/172756410790595930, 2009.

Cogley, J., Hock, R., Rasmussen, L., Arendt, A., Bauder, A., Braithwaite, R., Jansson, P., Kaser, G., Möller, M., Nicholson, L., and Zemp, M.: Glossary of Glacier Mass Balance and Related Terms, IHP-VII Technical Documents in Hydrology No. 86,, Tech. rep., IACS Contribution No. 2, UNESCO-IHP, Paris., 2011.

Cogley, J. G.: A more complete version of the World Glacier Inventory, Ann. Glaciol., 50, 32-38, 2009.

Davies, B. and Glasser, N.: Accelerating shrinkage of Patagonian glaciers from the Little Ice Age (AD 1870) to 2011, J. Glaciol., 58, 1363-1384, 2012.

Dowdeswell, J. A., Benham, T. J., Strozzi, T., and Hagen, J. O.: Iceberg calving flux and mass balance of the Austfonna ice cap on Nordaustlandet, Svalbard, J. Geophys. Res.-Earth, 113, F03022, doi:10.1029/2007JF000905, 2008.

Dunse, T., Schuler, T. V., Hagen, J. O., Eiken, T., Brandt, O., and Høgda, K. A.: Recent fluctuations in the extent of the firn area of Austfonna, Svalbard, inferred from GPR, Ann. Glaciol., 50, 155-162, doi:10.3189/172756409787769780, 2009.

Førland, E. J., Benestad, R., Hanssen-Bauer, I., Haugen, J. E., and Skaugen, T. E.: Temperature and Precipitation Development at Svalbard 1900-2100, Advances in Meteorology, 2011, 893790, doi:10.1155/2011/893790, 2011.

Frey, H. and Paul, F.: On the suitability of the SRTM DEM and ASTER GDEM for the compilation of topographic parameters in glacier inventories, Int. J. Appl. Earth Obs., 18, 480-490, doi:10.1016/j.jag.2011.09.020, 2012.

Fujisada, H., Bailey, G., Kelly, G., Hara, S., and Abrams, M.: ASTER DEM performance, IEEE T. Geosci. Remote, 43, 27072714, doi:10.1109/TGRS.2005.847924, 2005.

Fujisada, H., Urai, M., and Iwasaki, A.: Technical Methodology for ASTER Global DEM, IEEE T. Geosci. Remote, 50, 3725-3736, 2012.

Gjermundsen, E., Mathieu, R., Kaab, A., Chinn, T., Fitzharris, B., and Hagen, J.: Assessment of multispectral glacier mapping methods and derivation of glacier area changes, 19782002, in the central Southern Alps, New Zealand, from ASTER satellite data, field survey and existing inventory data, J. Glaciol., 57, 667-683, doi:10.3189/002214311797409749, 2011.

Haeberli, W. and Hoelzle, M.: Application of inventory data for estimating characteristics of and regional climate-change effects on 
mountain glaciers: A pilot study with the European Alps, Annals of Glaciology: Proceedings of the International Symposium On the Role of the Cryosphere In Global Change, Columbus Ohio 21 August 1994, , 1995.

Hagen, J. O., Liestøl, O., Roland, E., and Jørgensen., T.: Glacier atlas of Svalbard and Jan Mayen, Norwegian Polar Institue, Oslo, 1993.

Hagen, J. O., Melvold, K., Pinglot, F., and Dowdeswell, J. A.: On the net mass balance of the glaciers and ice caps in Svalbard, Norwegian Arctic, Arct. Antarct. Alp. Res., 35, 264-270, doi:10.1657/1523-0430(2003)035[0264:OTNMBO]2.0.CO;2, 2003.

Hamilton, G. and Dowdeswell, J.: Controls on glacier surging in Svalbard, J. Glaciol., 42, 157-168, 1996.

Hisdal, V.: Geography of Svalbard, vol. 2, Norwegian Polar Institue, Oslo, 1985.

Hoelzle, M., Chinn, T., Stumm, D., Paul, F., Zemp, M., and Haeberli, W.: The application of glacier inventory data for estimating past climate change effects on mountain glaciers: A comparison between the European Alps and the Southern Alps of New Zealand, Global Planet. Change, 56, 69-82, doi:10.1016/j.gloplacha.2006.07.001, 2007.

Howat, I. M. and Eddy, A.: Multi-decadal retreat of Greenland's marine-terminating glaciers, J. Glaciol., 57, 389-396, doi:10.3189/002214311796905631, 2011.

Humlum, O.: Modelling late 20th-century precipitation in Nordenskiöld Land, Svalbard, by geomorphic means, Norsk Geogr. Tidsskr., 56, 96-103, 2002.

Huss, M. and Farinotti, D.: Distributed ice thickness and volume of all glaciers around the globe, J. Geophys. Res., 117, F04010, doi:10.1029/2012JF002523, 2012.

James, T. D., Murray, T., Barrand, N. E., Sykes, H. J., Fox, A. J., and King, M. A.: Observations of enhanced thinning in the upper reaches of Svalbard glaciers, The Cryosphere, 6, 1369-1381, doi:10.5194/tc-6-1369-2012, 2012.

Jiskoot, H., Murray, T., and Boyle, P.: Controls on the distribution of surge-type glaciers in Svalbard, J. Glaciol., 46, 412-422, doi:10.3189/172756500781833115, 2000.

Jóhannesson, T., Raymond, C., and Waddington, E.: Time-scale for adjustment of glaciers to changes in mass balance, J. Glaciol., 35, 355-369, 1989.

Kääb, A., Paul, F., Maisch, M., Hoelzle, M., and Haeberli, W.: The new remote-sensing-derived Swiss glacier inventory: II. First results, Annals of Glaciology, Vol 34, 2002, 34, Int. Glaciol. Soc., NASA, US Natl. Sci. Fdn., doi:10.3189/172756402781817473, 2002.

Kohler, J., James, T. D., Murray, T., Nuth, C., Brandt, O., Barrand, N. E., Aas, H. F., and Luckman, A.: Acceleration in thinning rate on western Svalbard glaciers, Geophys. Res. Lett., 34, L18502, doi:10.1029/2007GL030681, 2007.

König, M., Nuth, C., Kohler, J., Moholdt, G., and Pettersen, R.: Global Land Ice Measurements from Space, chap. A Digitial Glacier Database for Svalbard, p. Ch. 10, Praxis-Springer, 2013.

Korona, J., Berthier, E., Bernard, M., Rémy, F., and Thouvenot, E.: SPIRIT. SPOT 5 stereoscopic survey of Polar Ice: Reference Images and Topographies during the fourth International Polar Year (2007-2009), ISPRS Journal of Photogrammetry and Remote Sensing, 64, 204-212, doi:10.1016/j.isprsjprs.2008.10.005, 2009.
Le Bris, R., Paul, F., Frey, H., and Bolch, T.: A new satellite-derived glacier inventory for western Alaska, Ann. Glaciol., 52, 135-143, doi:10.3189/172756411799096303, 2011.

Leclercq, P. and Oerlemans, J.: Global and hemispheric temperature reconstruction from glacier length fluctuations, Clim. Dynam., 38, 1065-1079, doi:10.1007/s00382-011-1145-7, 2012.

Lefauconnier, B. and Hagen, J. O.: Surging and calving glaciers in Eastern Svalbard, vol. 116, Norsk polarinstitutt, Oslo, 1991.

Martín-Español, A., Vasilenko, E., Navarro, F., Otero, J., Lapazaran, J., Lavrentiev, I., Macheret, Y., Machío, F., and Glazovsky, A.: Ice volume estimates from ground-penetrating radar surveys, western Nordenskiöld Land glaciers, Svalbard., Ann. Glaciol. 54, 211-217, 2013.

Moholdt, G. and Kääb, A.: A new DEM of the Austfonna ice cap by combining differential SAR interferometry with ICESat laser altimetry, Polar Res., 31, 18460, doi:10.3402/polar.v31i0.18460, 2012.

Moon, T. and Joughin, I.: Changes in ice front position on Greenland's outlet glaciers from 1992 to 2007, J. Geophys. Res., 113, F02022, doi:10.1029/2007JF000927, 2008.

Müller, F., Caflisch, T., and Müller, G.: Instructions for Compilation and Assemblage of Data for a World Glacier Inventory, Tech. rep., ETH Zürich.Temporary Technical Secretariat for the World Glacier Inventory., Z"urich, 1977.

Nick, F. M., Vieli, A., Howat, I. M., and Joughin, I.: Large-scale changes in Greenland outlet glacier dynamics triggered at the terminus, Nat. Geosci., 2, 110-114, doi:10.1038/ngeo394, 2009.

Nordli, Ø. and Kohler, J.: The early 20th century warming - Daily observations at Grønfjorden and Longyearbyen on Spitsbergen, Tech. rep., Norwegian Meteorological Institue, Oslo, 2004.

Nuth, C. and Kääb, A.: Co-registration and bias corrections of satellite elevation data sets for quantifying glacier thickness change, The Cryosphere, 5, 271-290, doi:10.5194/tc-5-271-2011, 2011.

Nuth, C., Kohler, J., Aas, H. F., Brandt, O., and Hagen, J. O.: Glacier geometry and elevation changes on Svalbard (1936-90): a baseline dataset, Ann. Glaciol., 46, 106-116, doi:10.3189/172756407782871440, 2007.

Oerlemans, J.: A flowline model for Nigardsbreen, Norway: projection of future glacier length based on dynamic calibration with the historic record, Ann. Glaciol., 24, 24, 382-389, 1997.

Oerlemans, J.: Glaciers and climate change, Balkema Publ., Lisse, 2001.

Oerlemans, J.: Extracting a Climate Signal from 169 Glacier Records, Science, 308, 675-677, doi:10.1126/science.1107046, 2005.

Østrem, G.: The Height of the Glaciation Limit in Southern British Columbia and Alberta, Geogr. Ann. A, 48, 126-138, http://www. jstor.org/stable/520522, 1966.

Paul, F., Kaab, A., Maisch, M., Kellenberger, T., and Haeberli, W.: The new remote-sensing-derived swiss glacier inventory: I. Methods, Ann. Glaciol., 34, 355-361, doi:10.3189/172756402781817941, 2002.

Paul, F., Barry, R., Cogley, J., Frey, H., Haeberli, W., Ohmura, A., Ommanney, C., Raup, B., Rivera, A., and Zemp, M.: Recommendations for the compilation of glacier inventory data from digital sources, Ann. Glaciol., 50, 119-126, doi:10.3189/172756410790595778, 2009.

Paul, F., Barrand, N., Baumann, S., Berthier, E., Bolch, T., Casey, K., Frey, H., Joshi, S., Konovalov, V., Bris, R. L., Mölg, N., 
Nosenko, G., Nuth, C., Pope, A., Racoviteanu, A., Rastner, P., Raup, B., Scharrer, K., Steffen, S., and Winsvold, S.: On the accuracy of glacier outlines derived from remote sensing data, Ann. Glaciol., 54, 171-182, doi:10.3189/2013AoG63A296, 2013.

Pfeffer, W. T., Sassolas, C., Bahr, D. B., and Meier, M. F.: Response time of glaciers as a function of size and mass balance: 2. Numerical experiments, J. Geophys. Res., 103, 9783-9789, doi:10.1029/98JB00508, 1998.

Racoviteanu, A. E., Arnaud, Y., Williams, M. W., and Ordonez, J.: Decadal changes in glacier parameters in the Cordillera Blanca, Peru, derived from remote sensing, J. Glaciol., 54, 499-510, doi:10.3189/002214308785836922, 2008.

Racoviteanu, A. E., Paul, F., Raup, B., Khalsa, S. J. S., and Armstrong, R.: Challenges and recommendations in mapping of glacier parameters from space: results of the 2008 Global Land Ice Measurements from Space (GLIMS) workshop, Boulder, Colorado, USA, Ann. Glaciol., 50, 53-69, 2009.

Radić, V. and Hock, R.: Regional and global volumes of glaciers derived from statistical upscaling of glacier inventory data, J. Geophys. Res., 115, F01010, doi:10.1029/2009JF001373, 2010.

Rastner, P., Bolch, T., Mölg, N., Machguth, H., Le Bris, R., and Paul, F.: The first complete inventory of the local glaciers and ice caps on Greenland, The Cryosphere, 6, 1483-1495, doi:10.5194/tc-6-1483-2012, 2012.

Raup, B., Kääb, A., Kargel, J. S., Bishop, M. P., Hamilton, G., Lee, E., Paul, F., Rau, F., Soltesz, D., Khalsa, S. J. S., Beedle, M., and Helm, C.: Remote sensing and GIS technology in the global land ice measurements from space (GLIMS) project, Comput. Geosci., 33, 104-125, doi:10.1016/j.cageo.2006.05.015, 2007.

Raup, B., Khalsa, S. J. S., Armstrong, R., and Racoviteanu, A.: The GLIMS Glacier Database: Status and Summary Analysis, in: MOCA09 - Our Warming Planet, IAMAS, IAPSO and IACS 2009 Joint Assembly, 2009.

Rotschky, G., Schuler, T. V., Haarpaintner, J., Kohler, J., and Isaksson, E.: Spatio-temporal variability of snowmelt across Svalbard during the period 2000-08 derived from QuikSCAT/SeaWinds scatterometry, Polar Res., 30, 5963, doi:10.3402/polar.v30i0.5963, 2011.

Sand, K., Winther, J. G., Marechal, D., Bruland, O., and Melvold, K.: Regional variations of snow accumulation on Spitsbergen, Svalbard, 1997-99, Nord. Hydrol., 34, 17-32, 2003.

Schiefer, E., Menounos, B., and Wheate, R.: An inventory and morphometric analysis of British Columbia glaciers, Canada, J. Glaciol., 54, 551-560, doi:10.3189/002214308785836995, 2008.
Schuler, T., Loe, E., Taurisano, A., Eiken, T., Hagen, J., and Kohler, J.: Calibrating a surface mass-balance model for Austfonna ice cap, Svalbard, Ann. Glaciol., 46, 241-248, doi:10.3189/172756407782871783, 2007.

Strozzi, T., Kouraev, A., Wiesmann, A., Wegmuller, U., Sharov, A., and Werner, C.: Estimation of Arctic glacier motion with satellite L-band SAR data, Remote Sens. Environ., 112, 636-645, 2008.

Sund, M., Eiken, T., Hagen, J. O., and Kääb, A.: Svalbard surge dynamics derived from geometric changes, Ann. Glaciol., 50, 5060, doi:10.3189/172756409789624265, 2009.

Svoboda, F. and Paul, F.: A new glacier inventory on southern Baffin Island, Canada, from ASTER data: I. Applied methods, challenges and solutions, Ann. Glaciol., 50, 11-21, doi:10.3189/172756410790595912, 2010.

Tachikawa, T., Kaku, M., Iwasaki, A., Gesch, D., Oimoen, M., Zhang, Z., Danielson, J., Krieger, T., Curtis, B., Haase, J., Abrams, M., Crippen, R., and Carabajal, C.: ASTER Global Digital Elevation Model Version 2 - Summary of Validation Results, Tech. rep., Joint Japan-US ASTER Science Team, 2011.

Taurisano, A., Schuler, T. V., Hagen, J. O., Eiken, T., Loe, E., Melvold, K., and Kohler, J.: The distribution of snow accumulation across the Austfonna ice cap, Svalbard: direct measurements and modelling, Polar Res., 26, 7-13, 2007.

Vieli, A., Funk, M., and Blatter, H.: Flow dynamics of tidewater glaciers: a numerical modelling approach, J. Glaciol., 47, 595606, 2001.

WGMS: World glacier inventory - Status 1988, IAHS (ICSI)/UNEP/UNESCO, World Glacier Monitoring Service, Zurich, Switzerland, 1989.

Winther, J. G., Bruland, O., Sand, K., Killingtveit, A., and Marechal, D.: Snow accumulation distribution on Spitsbergen, Svalbard, in 1997, Polar Res., 17, 155-164, 1998.

Wood, K. R. and Overland, J. E.: Early 20th century Arctic warming in retrospect, Int. J. Climatol., 30, 1269-1279, doi:10.1002/joc.1973, 2010.

Zwally, H., Schutz, R., Bentley, C., Bufton, J., Herring, T., Minster, J., Spinhirne, J., and Thomas., R.: GLAS/ICESat L2 Global ElevationData V33 [GLA14], Febuary 2003 to November 2009, NSIDC, Digital Media, available at: http://nsidc.org/data/icesat/ index.html, (last access: 1 September 2010), 2012. 